\title{
Bexarotene-Activated Retinoid X Receptors Regulate Neuronal Differentiation and Dendritic Complexity
}

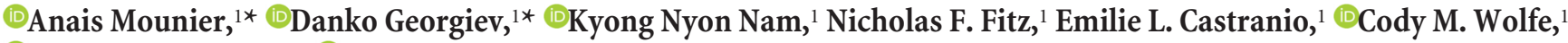 \\ 을 Andrea A. Cronican, ${ }^{1}$ - Jonathan Schug, ${ }^{2,3}$ Iliya Lefterov, ${ }^{1}$ and Radosveta Koldamova ${ }^{1}$ \\ ${ }^{1}$ Department of Environmental and Occupational Health, University of Pittsburgh, Pittsburgh, Pennsylvania 15219, and ${ }^{2}$ Institute for Diabetes, Obesity and \\ Metabolism and ${ }^{3}$ Functional Genomics Core, Department of Genetics, University of Pennsylvania, Philadelphia, Pennsylvania 19104
}

Bexarotene-activated retinoid X receptors (RXRs) ameliorate memory deficits in Alzheimer's disease mouse models, including mice expressing human apolipoprotein E (APOE) isoforms. The goal of this study was to gain further insight into molecular mechanisms whereby ligand-activated RXR can affect or restore cognitive functions. We used an unbiased approach to discover genome-wide changes in RXR cistrome (ChIP-Seq) and gene expression profile (RNA-Seq) in response to bexarotene in the cortex of APOE4 mice. Functional categories enriched in both datasets revealed that bexarotene-liganded RXR affected signaling pathways associated with neurogenesis and neuron projection development. To further validate the significance of RXR for these functions, we used mouse embryonic stem (ES) cells, primary neurons, and APOE3 and APOE4 mice treated with bexarotene. In vitro data from ES cells confirmed that bexaroteneactivated RXR affected neuronal development at different levels, including proliferation of neural progenitors and neuronal differentiation, and stimulated neurite outgrowth. This effect was validated in vivo by demonstrating an increased number of neuronal progenitors after bexarotene treatment in the dentate gyrus of APOE3 and APOE4 mice. In primary neurons, bexarotene enhanced the dendritic complexity characterized by increased branching, intersections, and bifurcations. This effect was confirmed by in vivo studies demonstrating that bexarotene significantly improved the compromised dendritic structure in the hippocampus of APOE4 mice. We conclude that bexarotene-activated RXRs promote genetic programs involved in the neurogenesis and development of neuronal projections and these results have significance for the improvement of cognitive deficits.

Key words: adult neurogenesis; APOE4 and APOE3; bexarotene; ChIP-Seq/RNA-Seq; neuronal differentiation; retinoid X receptor

Significance Statement

Bexarotene-activated retinoid X receptors (RXRs) ameliorate memory deficits in Alzheimer's disease mouse models, including mice expressing human apolipoprotein E (APOE) isoforms. The goal of this study was to gain further insight into molecular mechanisms whereby ligand-activated RXR can affect or restore cognitive functions. We used an unbiased approach to discover genome-wide changes in RXR cistrome (ChIP-Seq) and gene expression profile (RNA-Seq) in response to bexarotene in the cortex of APOE4 mice. Functional categories enriched in both datasets revealed that liganded RXR affected signaling pathways associated with neurogenesis and neuron projection development. The significance of RXR for these functions was validated in mouse embryonic stem cells, primary neurons, and $\mathrm{APOE} 3$ and APOE4 mice treated with bexarotene.

\section{Introduction}

Retinoid X receptors (RXRs) are nuclear receptors with complicated and poorly understood biology (Mangelsdorf et al., 1990; Evans and Mangelsdorf, 2014). In fact, some of the complex mo-

\footnotetext{
Received March 12, 2015; revised July 7, 2015; accepted July 17, 2015.

Author contributions: A.M., D.G., I.L., and R.K. designed research; A.M., D.G., K.N.N., N.F.F., E.L.C., C.M.W., A.A.C., J.S., I.L., and R.K. performed research; A.M., D.G., K.N.N., N.F.F., C.M.W., A.A.C., J.S., I.L., and R.K. analyzed data; I.L. and R.K. wrote the paper.

This work was supported by the National Institutes of Health (Grants AG037481, AG037919, ES024233, ES021243, and K01AG044490) and the Department of Defense (Grant W81XWH-13-1-0384).

The authors declare no competing financial interests.

*A.M. and D.G. contributed equally to this work.
}

lecular mechanisms used by RXR to interact with the genome and to regulate gene expression have only recently been revealed (Boergesen et al., 2012; Daniel et al., 2014). Ligand activated RXR, through permissive heterodimerization with other nuclear receptors [liver X receptors (LXRs), peroxisome proliferator-activated receptors (PPARs), or thyroid receptors] are involved in the development of phenotypes that can be disease associated. Acti-

Correspondence should be addressed to either lliya Lefterov, MD, PhD, or Radosveta Koldamova, MD, PhD, Department of Environmental and Occupational Health, University of Pittsburgh, 100 Technology Drive, BRIDG Building, Room 306, Pittsburgh, PA 15219, E-mail: iliyal@pitt.edu or radak@pitt.edu.

DOI:10.1523/JNEUROSCI.1001-15.2015

Copyright $\odot 2015$ the authors $\quad 0270-6474 / 15 / 3511862-15 \$ 15.00 / 0$ 
vated RXR can modulate those phenotypes and, in disease, some of the effects of the ligand-activated RXRs have been clearly categorized as therapeutic. For example, the synthetic RXR agonist bexarotene was US Food and Drug Administration approved for treatment of cutaneous T-cell lymphoma (Jawed et al., 2014).

Alzheimer's disease (AD) is characterized by cognitive decline, amyloid $\beta(\mathrm{A} \beta)$ plaques and tangles of hyperphosphorylated tau. The inheritance of $\epsilon 4$ allele of apolipoprotein E (APOE) is the major genetic risk factor for late-onset AD (Saunders et al., 1993). Human amyloid precursor protein (APP)-transgenic mice expressing human $\mathrm{APOE}$ isoforms in general recapitulate $\mathrm{AD}$ amyloid pathology, with APP/APOE4 displaying a higher level of amyloid plaques and worse cognitive performance than APP/ APOE3 (Bales et al., 2009; Fitz et al., 2012). APOE4 mice expressing endogenous mouse APP likewise exhibit memory impairments (Boehm-Cagan and Michaelson, 2014), a decreased dendritic complexity (Dumanis et al., 2009), and synaptic plasticity (Chen et al., 2010).

The role of RXR, presumably through LXR/RXR or RXR/ PPAR $\gamma$ permissive heterodimers, in in vitro and in vivo models of $\mathrm{AD}$ was first demonstrated more than a decade ago using the RXR ligand 9-cis-retinoic acid or LXR and PPAR $\gamma$ agonists (Koldamova et al., 2003; Heneka et al., 2005; Koldamova et al., 2005) and was later confirmed (Jiang et al., 2008; Donkin et al., 2010). RXR-LXR (Laffitte et al., 2001) and RXR-PPAR $\gamma$ (Claudel et al., 2001) heterodimers regulate APOE expression and synthetic agonists of these receptors have been considered for treatment of atherosclerosis. Recently, a promising therapeutic effect of bexarotene in APP mice has been reported (Cramer et al., 2012); however, the reduction in $\mathrm{A} \beta$ plaques after bexarotene treatment has not been replicated (Fitz et al., 2013; Price et al., 2013; Tesseur et al., 2013; Veeraraghavalu et al., 2013). Importantly, the remarkable effect of bexarotene on memory and cognitive performance was confirmed in APP/APOE4 (Fitz et al., 2013) and APOE4 mice (Boehm-Cagan and Michaelson, 2014). In two recent reports, it was demonstrated that bexarotene can affect brain function independently of $A \beta$ phenotype. In the first study, bexarotene treatment restored the behavior deficits in a mouse model of Parkinson's disease (McFarland et al., 2013) and, in the second, bexarotene reduced the increased cortical network hyperexcitability in Kv1.1 knock-out mice (Bomben et al., 2014).

The goal of the present study was to understand the molecular mechanisms by which liganded RXR can affect signaling pathways associated with cognition. Because the enhanced neurodegeneration in $\mathrm{AD}$ models affects the epigenomic landscape and transcriptome (Gjoneska et al., 2015), we worked with APOE4 mice expressing mouse APP. We applied high-throughput sequencing approaches to map RXR binding genome-wide and for RNA expression profiling in cortex of APOE4 mice treated with bexarotene. To determine the effect of bexarotene on RXR enrichment at binding sites, we performed gene-level analysis and intersected the results from ChIP-Seq datasets with the results from mRNA-Seq assays. We demonstrate that pathways involved in neuronal differentiation and neuronal projections were most significantly affected and chose those functional categories for further validation. Through validation assays using mouse embryonic stem (ES) cells, primary neurons, as well as brain tissue from APOE3 and APOE4 mice, we provide additional data suggesting that transcriptional control of networks of genes that regulate neuronal differentiation and neuritogenesis could be part of the effects of pharmacologically activated RXR in the brain. Therefore, our results have therapeutic implications for a number of neurodegenerative disorders.

\section{Materials and Methods}

Materials

All reagents, chemicals, and standard additives unless otherwise stated were purchased from Sigma-Aldrich Thermo Fisher.

\section{Experiments}

All animal experiments were approved by the University of Pittsburgh Institutional Animal Care and Use Committee.

\section{Mice}

APOE3 and APOE4 targeted replacement mice were originally purchased from Taconic on C57BL/6 background and maintained in-house on the same background. APOE3 and APOE4 mice and litters were used at 6 and 2 months of age. C57BL/6 mice were purchased from Hilltop Laboratory Animals and were used at 2 months of age. Animals were randomly assigned to either bexarotene $(100 \mathrm{mg} / \mathrm{kg} / \mathrm{d}$; oral gavage; Targretin; Eisai) or vehicle $(0.2 \mathrm{mg} / \mathrm{kg}$ glycerol $)$ treatment groups. To assess adult neurogenesis in the dentate gyrus (DG), $7 \mathrm{~d}$ after the beginning of bexarotene treatment, mice were injected with bromodeoxyuridine (BrdU, $100 \mathrm{mg} / \mathrm{kg}$, i.p.; BD Biosciences) twice, with an $8 \mathrm{~h}$ interval between injections. For quantification of adult neurogenesis (BrdU staining) and neurite morphology, male and female APOE3 and APOE4 mice were used.

\section{Rats}

Time pregnant Sprague Dawley rats were purchased from Taconic Biosciences and embryonic day 18 (E18) embryos were used to generate primary neuronal cultures.

\section{Processing of mouse brain tissue}

Mice were anesthetized with Avertin $(250 \mathrm{mg} / \mathrm{kg}$ body weight, i.p.) and perfused transcardially with $25 \mathrm{ml}$ of cold $0.1 \mathrm{M}$ PBS, pH 7.4 (Fitz et al., 2012). Brains were rapidly removed and divided into hemispheres. For ChIP-Seq and RNA isolation, the brains were dissected and snap frozen on dry ice. For immunohistochemistry, the hemispheres were fixed in $4 \%$ paraformaldehyde for $48 \mathrm{~h}$ and stored in $30 \%$ sucrose solution in PBS until sectioning.

\section{ChIP-Seq}

Cortices from male APOE4 mice treated with bexarotene for $10 \mathrm{~d}$ were used for ChIP-Seq. For ChIP, we used a rabbit polyclonal anti-RXR antibody $(\Delta \mathrm{N}$ 197, catalog \#sc-774; Santa Cruz Biotechnology) with an epitope corresponding to amino acids 198-462 representing the complete ligand-binding domain of human $\operatorname{RXR} \alpha$ and recommended for detection of $\operatorname{RXR} \alpha, \operatorname{RXR} \beta$, and RXR $\gamma$ of mouse, rat, and human origin. This antibody has been used for RXR ChIP-Seq of mouse liver in other studies (Boergesen et al., 2012). The quality of purified DNA (purity and fragment size) was evaluated on 2100 Bioanalyzer (Agilent Technologies).

ChIP libraries were generated according to our routine protocol using the NEB Next DNA Library Prep Master Mix Set (Koldamova et al., 2014). The libraries were validated for Illumina sequencing and sequencing performed on Illumina hiSeq 2000 instrument at the Functional Genomics Core, University of Pennsylvania, Philadelphia (http://fgc.genomics.upenn.edu/). $\mathrm{ChIP}$ and control input libraries were sequenced to 50 bases on an Illumina HiSeq 2000 instrument. Reads were aligned to mouse genome mm9 (NCBI Build 37) using Bowtie2 aligner (Langmead and Salzberg, 2012; http://bowtie-bio.sourceforge.net/bowtie2/), allowing up to two mismatches and requiring that the best alignment was unique, which produced between 30 and 61.4 million effective reads per library. We used Homer tools (http://homer.salk.edu/homer/ngs/index.html) for peak calling, annotation, and further processing of BAM/BED files.

For ChIP validation, we performed ChIP-qPCR and determined the percentage input normalized to the percentage input of negative control (target gene percentage input/negative control percentage input). Binding of RXR to mouse glucagon $(\mathrm{Gcg})$ or insulin (Ins) were used as negative controls.

\section{RNA isolation, $q P C R$, and sequencing}

Male APOE4 mice treated with bexarotene or vehicle $(n=3)$ were used for RNA-Seq. RNA was isolated from brain or cultured cells and purified 


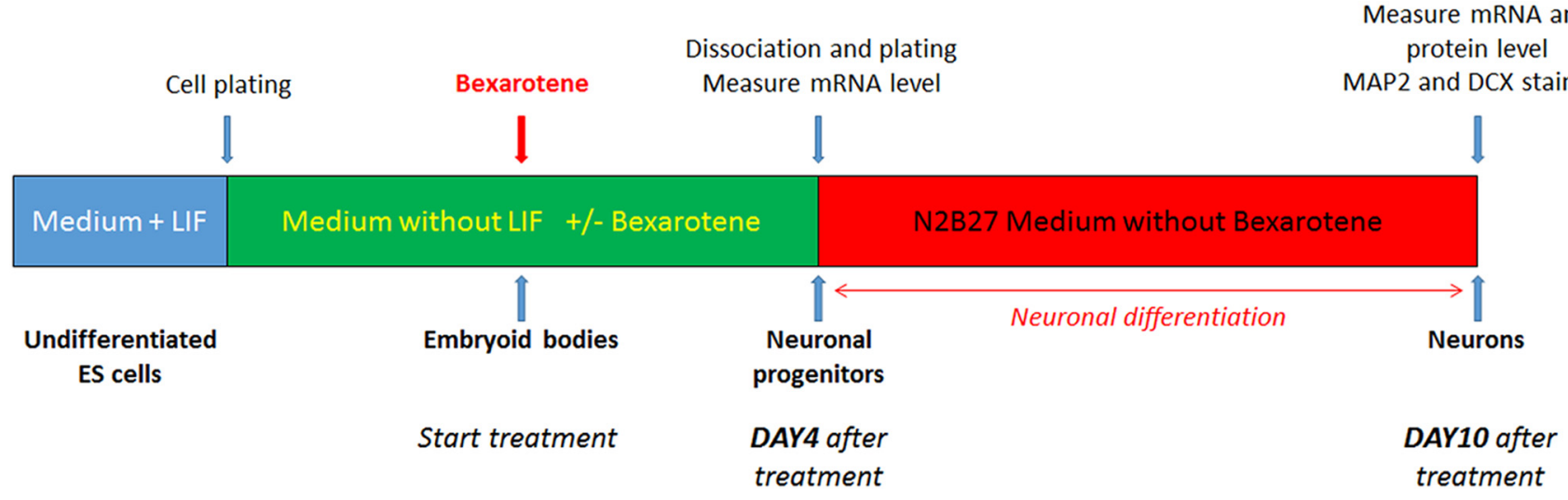

Figure 1. Outline of the protocol for mouse ES cell treatment and differentiation.

using the RNeasy kit (QIAGEN) according to the manufacturer's recommendations. The quality control of all RNA samples was performed on a 2100 Bioanalyzer instrument and samples with RIN $>8$ were further used for qPCR and library construction using mRNA Library Prep Reagent Set (Illumina). Libraries were generated by PCR enrichment including incorporation of barcodes to enable multiplexing. The libraries, three per condition, were sequenced on Illumina HiSeq 2000. For qPCR, first-strand cDNA was synthesized from $1 \mu \mathrm{g}$ of total RNA using EcoDry Premix, Random Hexamers (Clontech).

qPCR was performed using TaqMan Universal Master Mix II (Life Technologies). Transcript levels were normalized to Gapdh and amplification plots were analyzed with the comparative $\Delta \Delta \mathrm{Ct}$ method.

\section{Functional pathway analysis}

We performed functional annotation clustering using the Database for Annotation, Visualization and Integrated Discovery (DAVID; http://david.abcc.ncifcrf.gov/; Huang et al., 2009) and Ingenuity Pathway Analysis (IPA; www.qiagen.com/ingenuity; QIAGEN). IPA is a system that transforms a list of genes (with or without accompanying expression information) into a set of relevant networks based on extensive records maintained in the Ingenuity Pathways Knowledge Base (IPKB; Ficenec et al., 2003). For the RNA-Seq results, genes with their differential expression value (log ratio) were submitted, allowing the software to calculate a $z$-score, a statistical measure of correlation between relationship direction and gene expression. Therefore, we were able to determine the activation state of the significant functions represented by the genes we found to be regulated by bexarotene.

\section{ES cell treatment, qPCR, Western blotting, and immunostaining}

Cell culture and treatment. Mouse ES cells, line R1 (ATCC) were grown on gelatin $(0.1 \%)$-coated T75 flasks in standard ES cell culture medium composed of GMEM supplemented with $10 \%$ ES cells, qualified FBS, L-glutamine (2 mM), nonessential amino acids ( $0.1 \mathrm{~mm}), 2$-mercaptoethanol $(0.1 \mathrm{~mm})$, sodium pyruvate $(1 \mathrm{~mm})$, antibiotics, and $100 \mathrm{units} / \mathrm{ml}$ mouse leukemia inhibitory factor (mLIF; Life Technologies). Pharmacological effects on neuronal differentiation were tested using a previously published protocol (Bibel et al., 2007; see Fig. 1 for the design of in vitro experiments). Briefly, at the beginning of the assay, ES cells were plated in Petri dishes in medium without LIF to initiate the formation of embryoid bodies (EBs). EBs were treated with bexarotene, dissolved in DMSO, and used in concentrations from 0.1 to $5 \mu \mathrm{M}$. Vehicle (DMSO) was used as a negative control (Bibel et al., 2007). After $4 \mathrm{~d}$ of treatment, to initiate neuronal differentiation, the EBs were trypsin dissociated and plated on poly-L-ornithine/laminin-coated plates in N2B27 medium (DMEM high glucose + N2A and B27 supplements; Fig. 1). RNA was isolated $4 \mathrm{~d}$ after the start of the treatment and $6 \mathrm{~d}$ after plating, which corresponds to $10 \mathrm{~d}$ total after the start of the treatment. The effect on neuronal differentiation was examined by qPCR, Western blotting, and immunostaining.

$q P C R$. The following markers for neuronal progenitors were used: Nestin (Nes), Fatty Acid Binding Protein 7 (Fabp7), and Paired box 6
(Pax6) as suggested previously (Bibel et al., 2004). To further analyze neuronal differentiation, we used class III $\beta$-Tubulin (Tubb3), Vesicular Glutamate Transporter ( $v$ Glut1), Synaptophysin (Syp), and APP.

Marker visualization by immunostaining. We visualized doublecortin (DCX), a marker for developing neurons, and Microtubule-Associated Protein 2 (MAP2), which is expressed in both mature and developing neurons (Bibel et al., 2007). Briefly, ES cells were plated after $4 \mathrm{~d}$ of bexarotene treatment (Fig. 1) on poly-L-ornithine/laminin-coated 4 chamber slides at a density of $1 \times 10^{5}$ cells/chamber. Six days after plating, the cells were fixed with $4 \%$ formaldehyde, permeabilized with PBS-Triton $0.2 \%$, followed by $1 \mathrm{~h}$ blocking in PBS-Triton $0.2 \%$ solution with 3\% normal donkey serum. Primary antibodies were mouse antiMAP2 antibody (MAB378, 1:2000; Millipore) and goat anti-DCX antibody (sc-8066, 1:1000; Santa Cruz Biotechnology). Correspondingly, the secondary antibodies were donkey anti-mouse Alexa Fluor 488 and donkey anti-goat DyLight 594. Nuclear staining was performed with H33342. The slides were covered with Permafluor and visualized using a Nikon Eclipse 90i fluorescent microscope (20× objective). The number of neuronal cells positive for each marker was calculated from four to six images per condition.

\section{Adult neurogenesis}

Immunohistochemistry. Two-month-old APOE3 and APOE4 male and female mice were used. Thirty micron coronal sections were collected in six separate series containing every sixth section spanning the entire rostralcaudal extent of the DG from bregma $-1.2 \mathrm{~mm}$ to bregma $-3.9 \mathrm{~mm}$ (Franklin and Paxinos, 2007) and used for unbiased stereological assessment of BrdU+ cells. For BrdU antigen retrieval, sections were incubated in $70 \%$ formamide $/ 30 \% 2 \times \mathrm{SSC}$ at $70^{\circ} \mathrm{C}$ for $2 \mathrm{~h}$, followed by $2 \mathrm{~N} \mathrm{HCl}$ at $37^{\circ} \mathrm{C}$ for 30 min. Sections were then washed in PBS, permeabilized in $0.2 \%$ Triton $\mathrm{X}-100 / \mathrm{PBS}$ for $30 \mathrm{~min}$, and blocked in 3\% normal goat serum for $1 \mathrm{~h}$. Primary rat anti-BrdU antibody (OBT0030G, 1:200; Accurate Chemical) was applied in blocking solution for $40 \mathrm{~h}$ at $4^{\circ} \mathrm{C}$, followed by secondary goat anti-rat Alexa Fluor 488 antibody (1:500) incubated at room temperature for $2 \mathrm{~h}$. Stained sections were mounted on glass slides with Permafluor.

Stereology. Large images covering the entire DG were obtained with a Nikon $90 \mathrm{i}$ microscope using a $20 \times$ objective. The images were taken using the EDF module (enhanced depth of focus) in NIS elements, which allows for a more focused image. Accurate estimates of BrdU+ cell numbers required implementation of an exhaustive sampling scheme in 15 sections spanning the entire rostral-caudal extent of the DG of each animal. The number of BrdU + cells sampled was then multiplied by 6 to obtain the total number of BrdU + cells per DG (Ngwenya et al., 2005).

Primary neuronal cultures, imaging, and Sholl analysis

Primary neuronal cultures were prepared from E18 rat embryos as described previously (Koldamova et al., 2003). A single-cell suspension was used and cells plated at a density of $10^{5}$ cells $/ \mathrm{cm}^{2}$ on $18 \mathrm{~mm}$ circular coverslips (VWR) (coated with $0.01 \%$ poly-L-lysine) in neurobasal medium containing antibiotics, L-glutamine, and B27 supplement. Cultures were maintained by replacing $50 \%$ of the conditioned medium with fresh 
A

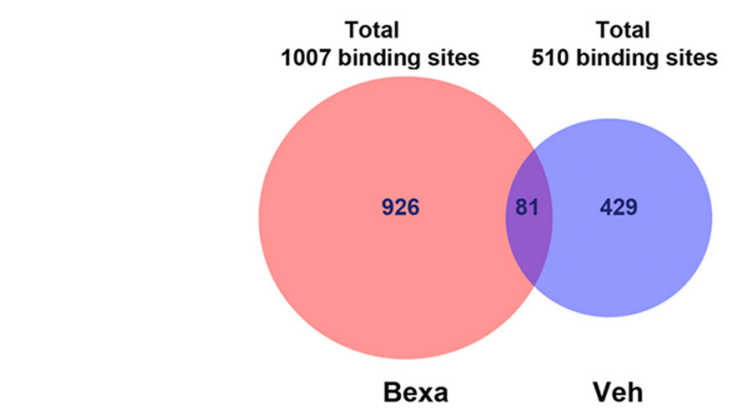

C

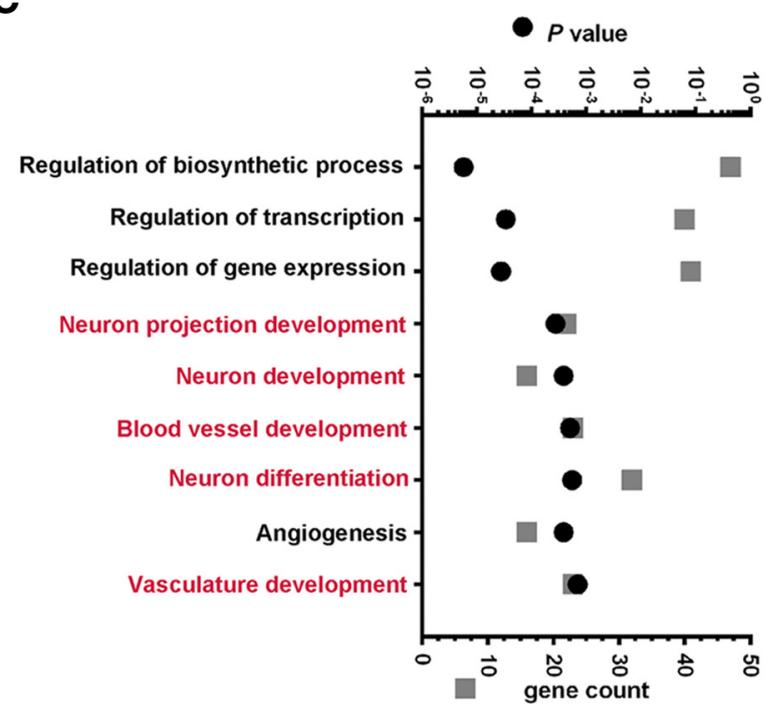

B

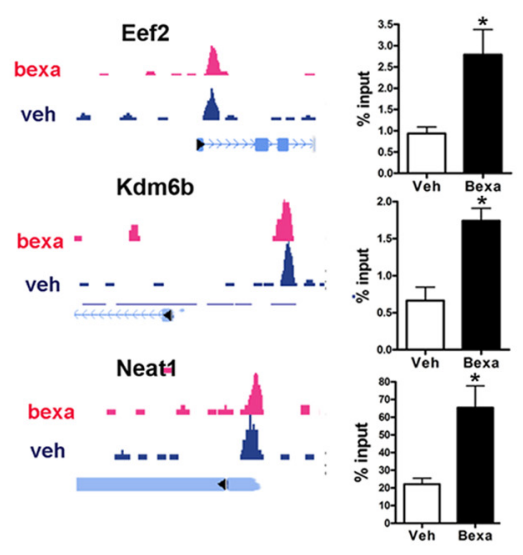

D

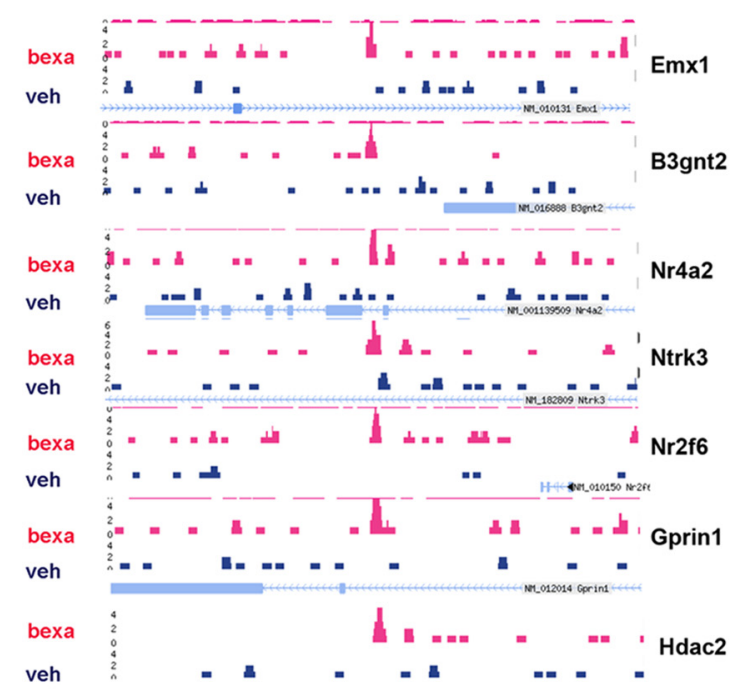

\section{E RXR binding to genes associated with neuronal differentiation}

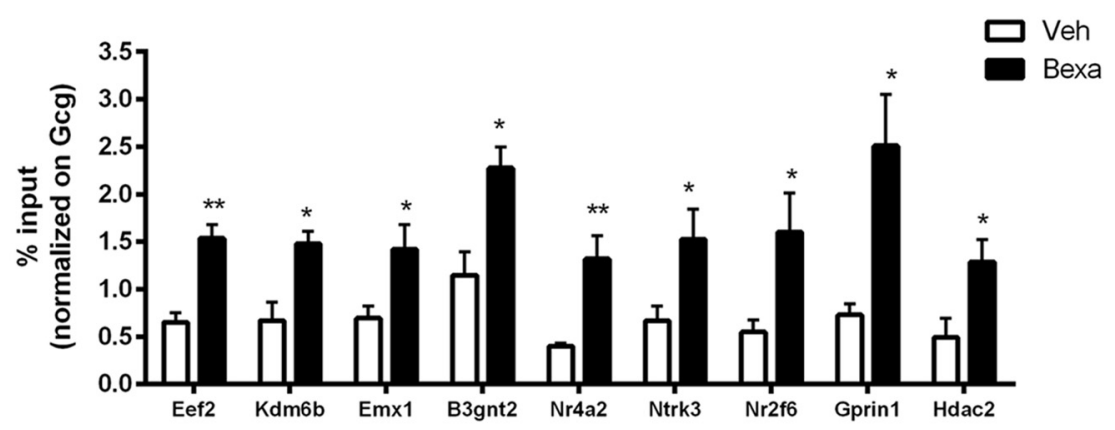

Figure 2. ChIP-Seq data revealing that bexarotene-activated RXR binds genes associated with neuronal differentiation in brain of APOE4 mice. Six-month-old APOE4 mice were treated with bexarotene for $10 \mathrm{~d}$ and ChIP-Seq was performed on DNA immunoprecipitated with an antibody against RXR. $\boldsymbol{A}$, Venn diagram showing the number of overlapping peaks in bexarotene- and vehicle-treated APOE4 mice. $\boldsymbol{B}$, Binding sites in a genome browser identified in both bexarotene-and vehicle-treated APOE4 mice. The corresponding ChIP-qPCR validation data of these targets performed on cortices from WT mice treated $24 \mathrm{~h}$ with bexarotene are shown on the right. C, Most significant functional annotation categories (GOTERM Biological Process) of direct RXR target genes. In red are categories identical in ChIP-Seq and RNA-Seq datasets. $\boldsymbol{D}$, Genome browser view of RXR binding to sites in the proximal promoters of or nearby genes related to neuronal differentiation (BP category "G0:0030182 neuron differentiation") and unique for bexarotene-treated APOE4 mice. $\boldsymbol{E}$, RXR-binding sites of the indicated individual genes associated with neuronal differentiation were confirmed by ChIP-qPCR in P19 cells treated with $100 \mathrm{~nm}$ bexarotene for $6 \mathrm{~h}$. Values are mean \pm SEM. For $\boldsymbol{B}$ and $\boldsymbol{E}, n=3-4{ }^{* *} p<0.01 ;{ }^{*} p<0.05$. Blue color denotes vehicle samples and red bexarotene in all panels.

medium every fourth day. At the day of dissection (zero days in vitro, DIV0), cells were infected at a multiplicity of infection of 0.2 with GFPlentivirus particles packaged with the pLVX-IRES-ZsGreen1 Vector (Clontech). The moderate efficiency of this infection technique allows an easy identification of the processes associated with single neurons. At DIV4, infected neurons were treated with $1 \mu \mathrm{M}$ bexarotene or vehicle for $24 \mathrm{~h}$, following by washing and medium replacement. Six days later (at DIV11), the neurons were fixed with $4 \%$ paraformaldehyde for $30 \mathrm{~min}$ at 
Table 1. IPA functional annotations of RNA-Seq data

\begin{tabular}{lccc}
\hline IPA functions annotation & $p$-value & Activation z-score & No. of molecules \\
\hline Cognition & $3.70 \mathrm{E}-10$ & 3.9 & 51 \\
Development of neurons & $1.72 \mathrm{E}-12$ & 3.2 & 81 \\
Microtubule dynamics & $1.37 \mathrm{E}-10$ & 2.6 & 105 \\
Proliferation of neuronal cells & $7.27 \mathrm{E}-09$ & 2.5 & 59 \\
Outgrowth of neurites & $3.21 \mathrm{E}-07$ & 2.4 & 42 \\
Neuritogenesis & $7.34 \mathrm{E}-10$ & 2.3 & 61 \\
Behavior & $1.99 \mathrm{E}-14$ & 2.1 & 103 \\
Differentiation of neurons & $3.22 \mathrm{E}-10$ & 1.9 & 48 \\
Neuronal cell death & $6.01 \mathrm{E}-10$ & -0.8 & 69 \\
Apoptosis of neurons & $1.75 \mathrm{E}-06$ & -1.9 & 42 \\
\hline
\end{tabular}

Highly significant IPA functional annotations are represented with their corresponding activation state.

room temperature, counterstained with $\mathrm{H} 33342$, and multichannel GFP-H33342 images $(1392 \times 1040$ pixels $)$ were captured with a Nikon $90 \mathrm{i}$ microscope using a $20 \times$ objective.

Neuronal reconstruction and morphological analysis. For each treatment group, at least nine wells and no less than two GFP+ neurons per well were imaged. H33342 staining was used to verify that only single neurons, not cell clusters, were selected for reconstruction. The GFP channel of each captured image was then exported as a TIF file, and individual neurons were semiautomatically reconstructed using Neuromantic (Myatt et al., 2012). Neuronal reconstructions, saved as SWC files, were used for subsequent morphometric analyses with Neuromantic. Sholl analysis was additionally performed using the Trees Toolbox (Cuntz et al., 2011) for MATLAB (The MathWorks).

\section{Neurite quantification in APOE3 and APOE4 mice}

Neurite morphometry analysis was performed as described previously with slight modification (Tapias et al., 2013; Tapias and Greenamyre, 2014). Two-month-old APOE 3 and APOE4 male and female mice were used for the neurite morphology analysis. For immunofluorescence labeling, sectioning was performed as described above and sections sampled starting $450 \mu \mathrm{m}$ from the first appearance of the DG and every 360 $\mu \mathrm{m}$ (four total sections). Sections were rinsed in PBS and permeabilized with $1 \%$ Triton X-100 in PBS for $5 \mathrm{~h}$ at $4^{\circ} \mathrm{C}$. The sections were then washed in PBS and blocked with $10 \%$ goat serum for $30 \mathrm{~min}$ at room temperature (RT). The sections were incubated for $72 \mathrm{~h}$ at $4^{\circ} \mathrm{C}$ with MAP2 primary antibody (MAB378, 1:2000; Millipore) and for another $1 \mathrm{~h}$ at RT before being rinsed with PBS and then incubated with Cy3conjugated anti-mouse secondary antibody (1:500) for $2 \mathrm{~h}$ at RT. Sections were washed in PBS, mounted onto Fisherbrand Superfrost plus coated slides, counterstained with H33342 nuclear reagent, and coverslipped. Fluorescence images were captured using a confocal microscope (Olympus Fluoview 1000) and quantification was performed at $60 \times$ magnification at a very high resolution $(100 \mu \mathrm{s})$. Analysis was performed on four confocal images from the CA1 region for each of the four sections per animal. The FilamentTracer module of Imaris (Bitplane), which facilitates neuron reconstruction, was used to determine neuronal patterning and connections of hippocampal brain sections. The MAP2 (Cy3) channel was used to quantify total neurite length, the number of segments, and the number of branches in the CAl region of the hippocampus. For unbiased examination, the size and the length of the neurites were the only parameters that required manual introduction. For parity, image assessment was conducted using identical grid dimensions. Neurite length was normalized to the number of H33342-stained nuclei.

\section{Statistics}

All results are reported as means \pm SEM. All statistical analyses (if not otherwise mentioned in the text and figure legends) were performed in GraphPad Prism version 6.0 and differences were considered significant at $p<0.05$. Links to statistics and software packages used to analyze the sequencing datasets will be provided upon request.

\section{Results}

\section{ChIP-Seq data reveal ligand-activated RXRs bind to genes associated with neuronal differentiation in brain of APOE4 mice}

To determine RXR binding genome wide, we performed ChIP followed by massive parallel sequencing (ChIP-Seq) using cortices from APOE4 mice treated with bexarotene. Regions of enrichment in the RXR datasets were identified and compared with the corresponding regions in the input datasets using HOMER software routines and a false discovery rate (FDR) threshold of 0.01 . We identified 510 genomic sites in vehicle-treated mice and 1007 in bexarotene-treated mice (Fig. 2A), suggesting increased binding of liganded RXR to target genes. There were 81 common binding sites in both conditions among them Eef2 (Eukaryotic Elongation Factor; Ma et al., 2014), Kdm6b (Histone 3 Lysine 27 [H3K27] Demethylase 6b; Li et al., 2014a; Li et al., 2014b), and Neat1 (Nuclear paraspeckle assembly transcript 1; Ottaviani et al., 2014). To validate the results of analyzed sequencing datasets, we performed ChIP-qPCR using cortices of mice treated with bexarotene. As shown in Figure $2 B$, bexarotene increased RXR binding to Eef2, Kdm6b, and Neat1 binding sites. We determined the gene ontology (GO) categories in both conditions using DAVID (Huang et al., 2009). Functional annotation clustering revealed a unique set of biological process (BP) ontologies that were significantly enriched in bexarotene versus control samples. In fact, the only category of annotated genes shared between bexarotene and control samples was regulation of transcription (data for vehicle not shown). We were particularly interested in the genomic sites enriched by bexarotene-treated samples (Fig. $2 C)$. Functional annotation charts demonstrated that, among the significantly enriched BP ontologies, the unique binding sites were clustered in categories such as "neuron projections development," "neuron differentiation," and "neuron development" (Fig. 2C,D). Interestingly, similarly to a recent study examining the effect of bexarotene on RXR binding to the entire mouse genome (Daniel et al., 2014), one of the categories in our data that was the most significantly affected was "angiogenesis." To validate ChIP-Seq data, we performed ChIP-qPCR to determine how bexarotene affects RXR binding to select annotated sites in P19 neuronal cell line. As shown in Figure 2E, bexarotene significantly increased RXR binding to genes related to neuronal differentiation and neuron projection.

\section{RNA-Seq data identify significant changes in genes related to neuronal differentiation and neuron projections in bexarotene treated APOE4 mice}

Next, we used RNA-seq to determine bexarotene-induced effects on the transcriptome of APOE4 brains. Using FDR $\leq 0.01$ as a cutoff, we found 551 upregulated and 227 downregulated genes. To predict the activation state of the functions of interest, we used a web tool available from Ingenuity (IPA). As shown in Table 1, an increased activation by bexarotene was predicted in the categories "learning," "development of neurons," and "neuritogenesis" (activation $z$-score, 3.9, 3.2, and 2.3, respectively), whereas a decreased activation state was predicted for "neuronal cell death" and "apoptosis of neurons" ( $z$-score, -0.8 and -1.9 , respectively). Importantly, in terms of diseases, IPA results revealed that the most affected disease categories were "Alzheimer's disease" and "tauopathy" ( $p=2.37$ E-10 and 2.24 E-10, respectively).

GO analysis by DAVID revealed categories of genes in GO term BP with a very low $p$-value, clustered in groups, that are highly significant for neuron development, neuron differentiation, and neuron projection development (Fig. 3A). To validate 


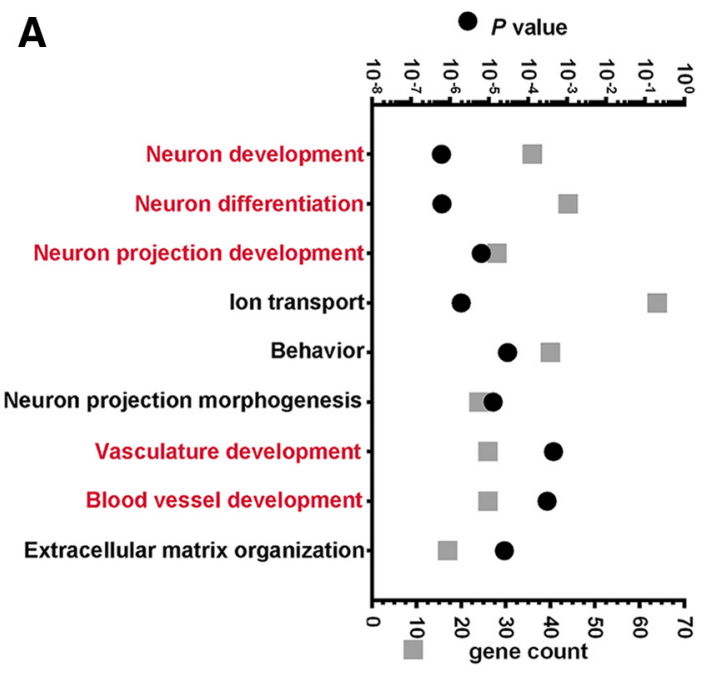

C

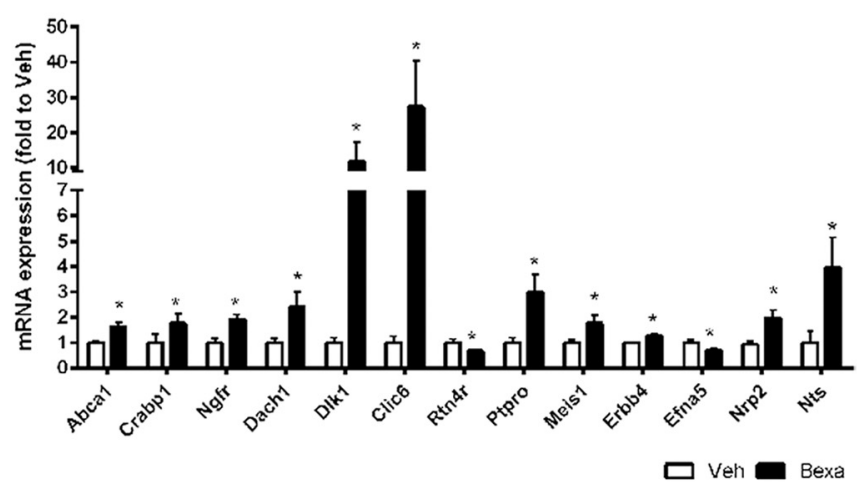

B

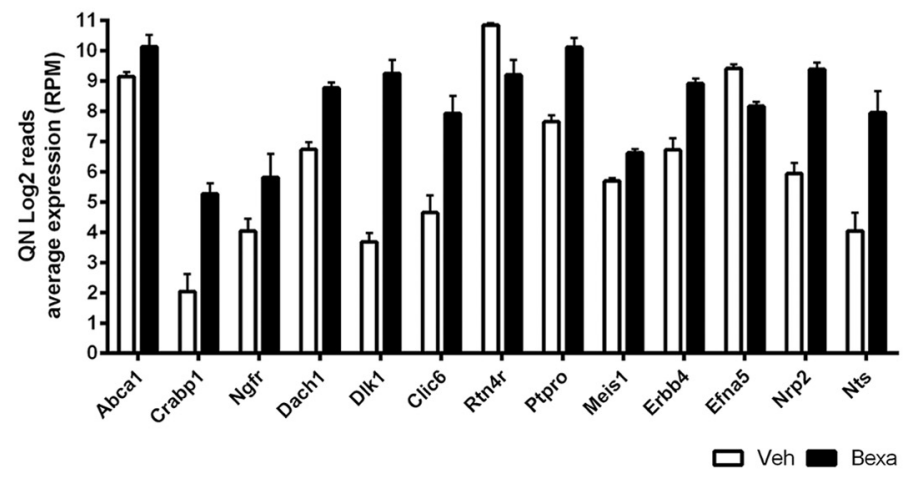

D

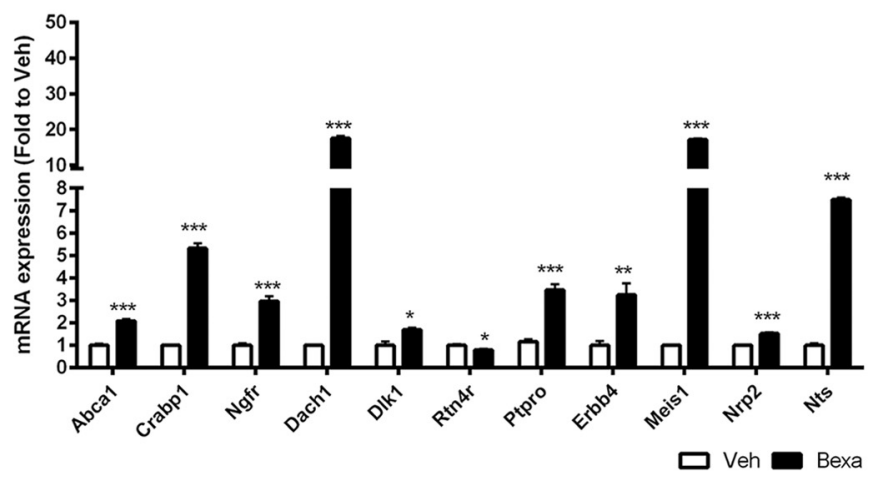

Figure 3. RNA-Seq results demonstrating that bexarotene significantly affects genes related to neuronal differentiation and neuron projection. Six-month-old APOE4 mice treated with bexarotene or vehicle ( $n=3$, males) were used for RNA-Seq. Differential gene expression analysis using edgeR identified 551 upregulated and 227 downregulated genes at FDR $<0.01$. $A$, Statistically significant functional annotation categories (GOTERM Biological Process) were determined by DAVID using a custom gene list generated at FDR $<0.01$. In red are depicted GOTERM categories identical in ChIP-Seq and RNA-Seq datasets. $n=3$ mice per group. $\boldsymbol{B}$, RNA expression level of significantly changed genes identified by RNA-Seq in categories "neuronal differentiation" and "neuron projection development." Plotted are log2-normalized reads per million (RPM) of genes with a fold change of at least 2-fold. Abca1 is shown to confirm a target engagement. Statistic is by edgeR, FDR $<0.01, n=3$. C, Validation of RNA-Seq results by qPCR using total RNA obtained from cortices of APOE4 mice. $n=5$ male and 4 female mice per group. $D$, Validation of the RNA-Seq results by qPCR using ES cells. ES cells at the EB stage (Fig. 1) were treated with $5 \mu \mathrm{m}$ bexarotene and vehicle for $24 \mathrm{~h}$. For (and $\boldsymbol{D}$, statistics is by $t$ test; $n=4,{ }^{*} p<0.05^{* *} p<0.001$ and ${ }^{* * *} p<$ 0.0001 .

RNA-Seq data, we chose genes from categories related to neuronal differentiation, neurite growth, and neuritogenesis at an FDR $\leq 0.01$ threshold with a fold change (FC) of at least twofold. Some of these genes, such as as Dlk1 (Delta-like homolog 1); Ptpro (protein tyrosine phosphatase, receptor type, O), and Crabp1 (cellular retinoic acid binding protein I), were identified by ChIP-Seq data as well, confirming that they are direct RXR target genes (see also Fig. 4A). Dlkl, the gene with highest fold increase, is a noncanonical Notch ligand involved in differentiation of adipocytes and neurons and in adult neurogenesis (Falix et al., 2012). Interestingly, increased enrichment of RXR binding to Notch1 was identified by ChIP-Seq data (Fig. 4A) and, whereas Notch 1 was upregulated $(\mathrm{FC}=1.8$-fold, FDR $=0.029)$, it did not pass our FDR cutoff criteria for the RNA-Seq data list used for functional annotation clustering. Furthermore, although its role in the brain is not well known (Penton et al., 2012), Notch2 was also identified as being differentially expressed ( $\mathrm{FC}=2.2$-fold, FDR $=0.0003$ ), suggesting RXR involment in the Notch pathway. Ptpro is a nonreceptor protein phosphatase involved in ephrin-A2 signaling and was shown to affect axonal growth and to control the branch morphology of developing neurons (Shintani et al., 2006; Miao and Wang, 2012). Crabp1 was reported to be upregulated during differentiation of monkey ES cells into astrocyte progenitors (Akama et al., 2013). The significantly affected genes were validated first in APOE4 cortex (Fig. $3 C$ ) and then in ES cells (Fig. 3D). Both sets of qPCR data confirmed the validity of the RNA-Seq results.

\section{Overlapping signatures identified by RXR binding and gene expression analysis}

Functional categorization using IPA and GO analyses of ChIPSeq and RNA-Seq data identified overrepresented genes (Fig. 4) associated with differentiation of neurons, neurite growth, and neuritogenesis as regulated by bexarotene in the cortex of APOE4 mice. ChIP-Seq data revealed that bexarotene increased the enrichment to 30 genomic sites corresponding to genes associated with these categories (Fig. 4A). Interestingly, $30 \%$ of these genes are transcription factors or chromatin modifiers, indicating that RXR activation can affect gene expression indirectly through molecular mechanisms mediated by complex gene networks and not 


\section{A ChIP-seq : Differentiation of neurons, neurite growth, neuritogenesis}

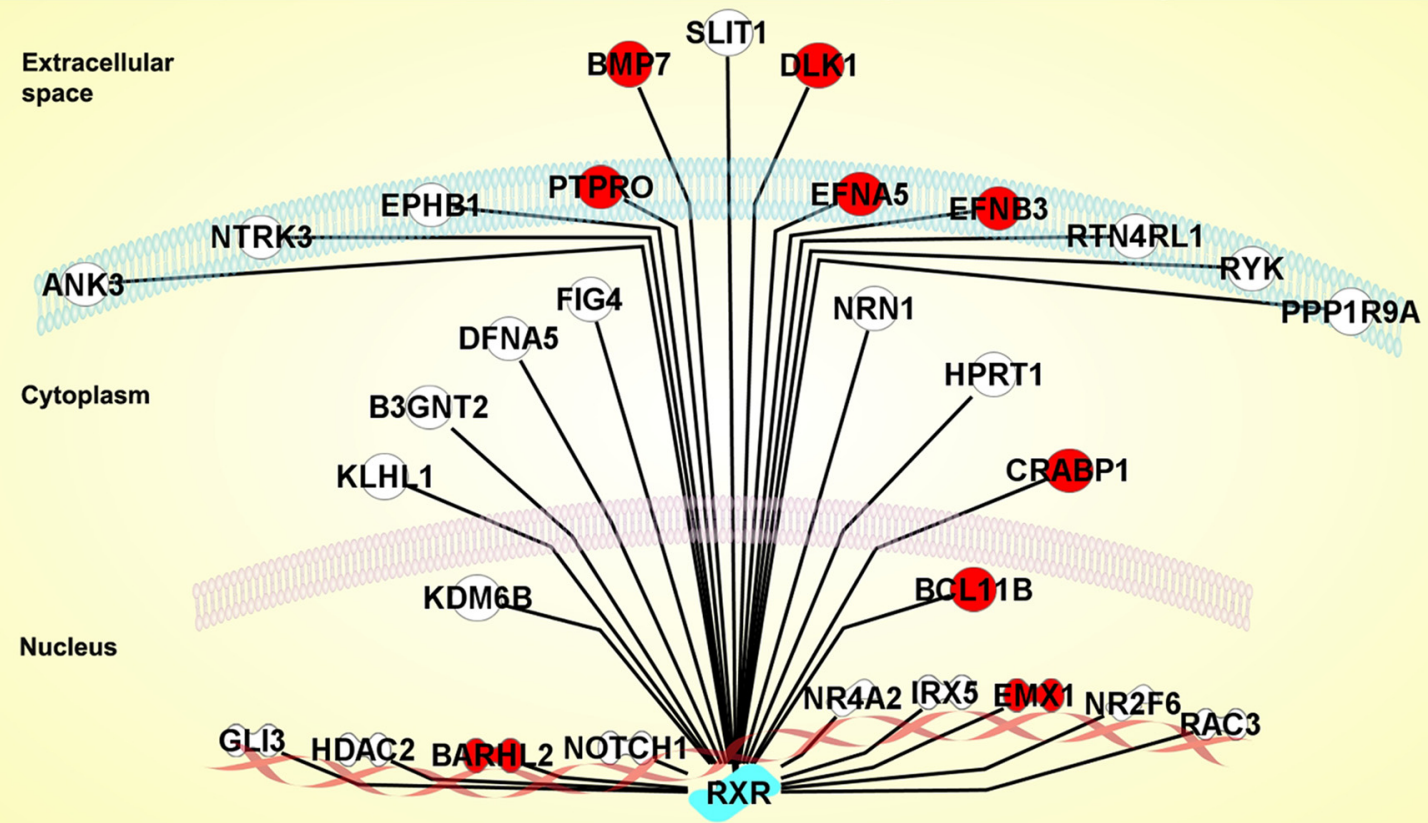

B RNA-seq : Differentiation of neurons, neurite growth, neuritogenesis

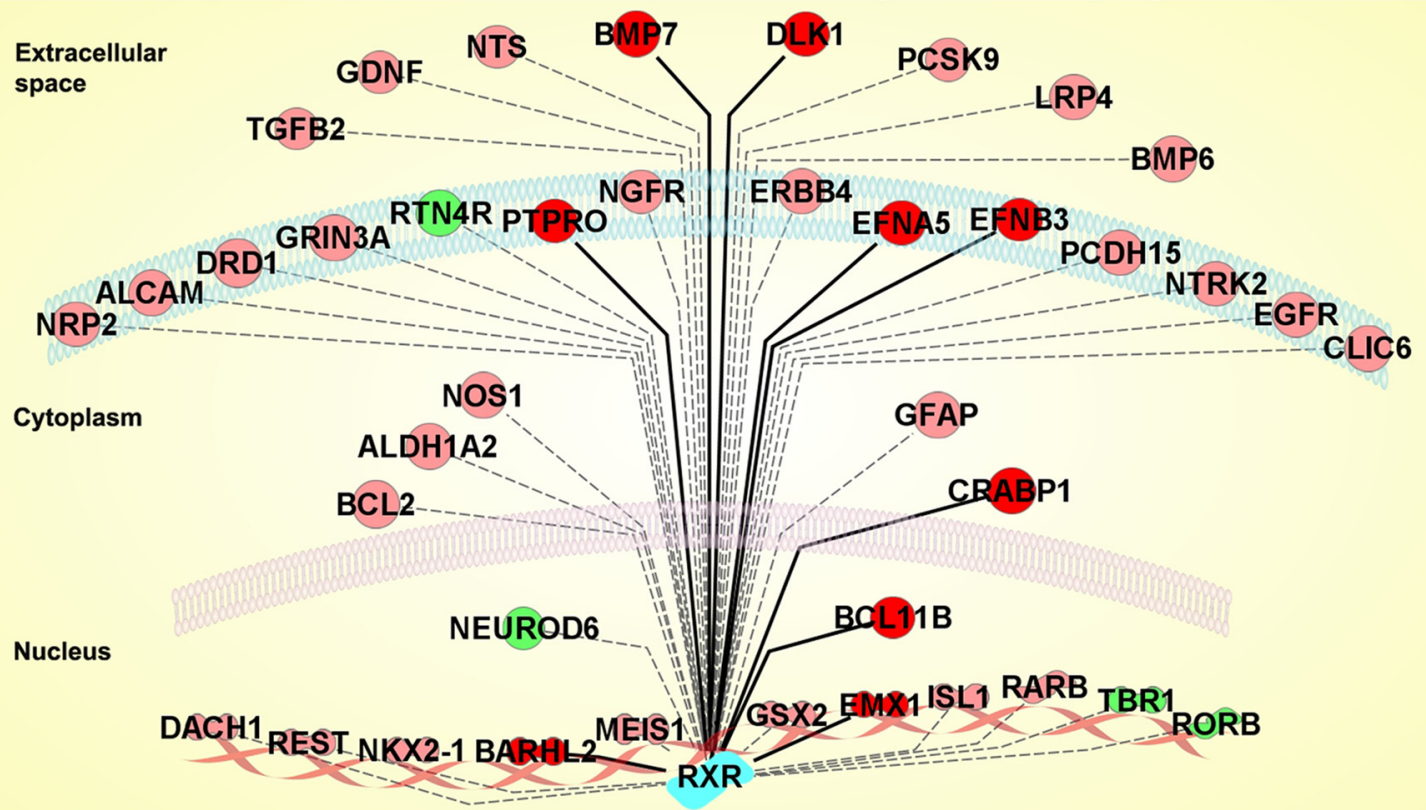

Figure 4. Comparative pathway analysis of ChIP-Seq and RNA-Seq data. Shown are IPA analyses of RXR ChIP-Seq $(\boldsymbol{A})$ and RNA-Seq ( $\boldsymbol{B})$ data identifying a network of genes associated with differentiation of neurons, neurite growth, and neuritogenesis regulated by bexarotene in the cortex of APOE4 mice. For ChIP-Seq, genomic sites uniquely identified only in bexarotene-treated mice were submitted, and for RNA-seq, only differentially expressed genes at an FDR of $\leq 0.01$ were submitted. RXR binding to target genes identified by ChIP-Seq is represented by thick lines and genes identified only by RNA-Seq by dotted lines. Red color depicts genes overlapping in both sets; pink indicates upregulated genes and green downregulated genes; the genes that did not meet the $\mathrm{FDR}=0.01$ cutoff in the RNA-Seq data are colorless. The picture was generated using the IPA web tool.

only through homodimerization or heterodimerization with other nuclear receptors. Similarly, IPA and GO analysis of differentially expressed genes (cutoff at FDR $\leq 0.01$ ) identified $>60$ genes in the annotation categories "differentiation of neurons," "neurite growth," and "neuritogenesis," the most relevant of which are shown in Figure $4 B$. Common genes overlapping between ChIP-Seq and RNA-Seq datasets included Dlk1, Ptpro, $C r a b p 1, B m p 7$, ephrin-related receptors Efna5 and Efnb3, and the transcription factors Barhl2 and Emxl. The transcriptional factor
Barhl1 belongs to a subfamily of mammalian homeobox genes and is expressed in migrating neurons of the CNS (Bulfone et al., 2000). Emx1 and Emx2 genes are expressed in the developing cerebral cortex and are involved in the patterning of the rostral brain (Cecchi and Boncinelli, 2000). Except for Efna5 and Emx1, all genes overlapping in both datasets were upregulated by bexarotene. Other genes from a common pathway that were included in these categories and discovered in both ChIP-Seq and RNA-Seq data were two Nogo receptors. Reticulon 4 receptor 
A

Neuronal lineage markers
B Neuronal differentiation markers: Tubb3 and Syp

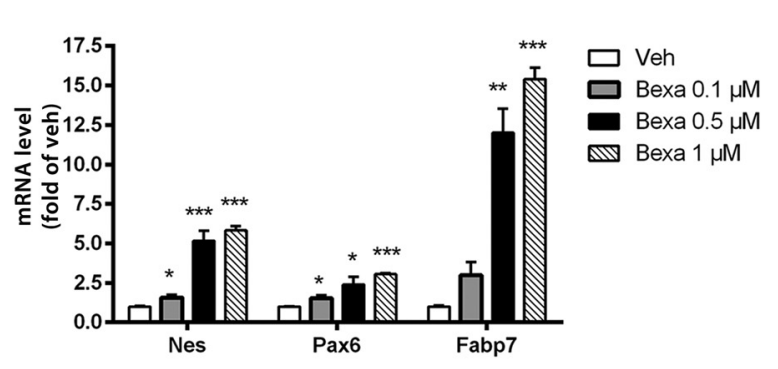

C

Neuronal differentiation markers: APP and Vglut1

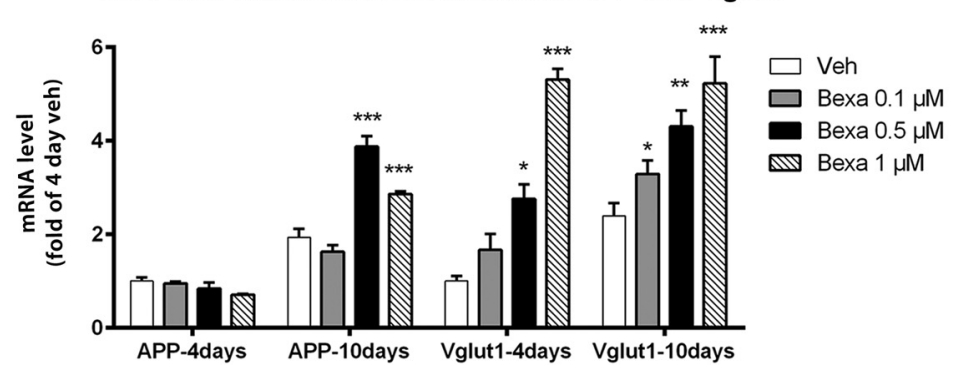

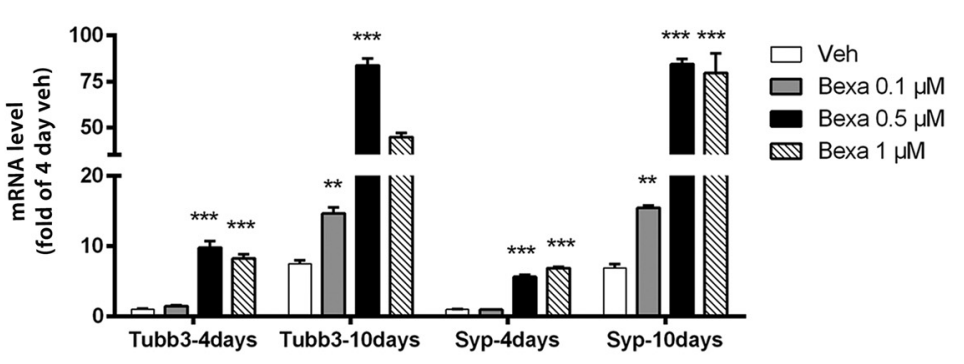

D

Figure 5. Bexarotene facilitates the commitment of ES cells to neuronal lineage and increases neuronal differentiation. ES cells were treated with bexarotene (0.1-1 $\mu \mathrm{m}$ ) as shown in Figure 1. $A$, Bexarotene increases the expression of neuronal precursor markers. ES cells were treated for $4 \mathrm{~d}$ with increasing concentrations of bexarotene and the expression of the specific neuronal progenitor markers Nes, Pax6, and Fabp7 was examined by qPCR. Transcript levels were normalized to Gapdh. Analysis is by one-way AN0VA ( $p<0.0001$ for each gene). Results for Tukey's posttest are shown on the graph: ${ }^{* *} p<0.001$ and ${ }^{* * *} p<0.0001$ versus vehicle. $\boldsymbol{B}-\boldsymbol{D}$, Bexarotene increases the expression level of markers for neuronal differentiation. $\boldsymbol{B}$, $\boldsymbol{C}$, mRNA expression was examined on days 4 and 10. Markers for differentiation were Tubb3, Syp, vGlut1, and APP. Transcript levels were normalized to Gapdh. The level of expression of each marker is presented as fold of day 4 . One-way ANOVA $p<0.001$ for each time point except for APP at day 4. Results for Tukey's posttest are shown on the graph. ${ }^{*} p<0.05,{ }^{* *} p<0.001$, and ${ }^{* * *} p<0.0001$ versus vehicle. $\boldsymbol{D}$, Bexarotene increases SYP protein level. ES cells were treated with 0.5 or $5 \mu \mathrm{m}$ bexarotene and SYP protein expression was determined at day 10 by Western blotting. The image is a representative of three samples per condition. The graph represents the SYP protein level as fold of vehicle control.

(Rtn4r or Nogo-66 receptor) was significantly downregulated by bexarotene (Figs. $3 B, 4 B$ ). As shown in Figure $3, C$ and $D$, the effect of bexarotene on Rtn $4 r$ mRNA was validated by qPCR in APOE4 brain and in ES cells, respectively. As revealed by ChIPSeq data (Fig. $4 A$ ), bexarotene increased RXR enrichment to Rtn4r homolog reticulon 4 receptor-like 1 (Rtn4rl1). From the data presented in Figures 2, 3, and 4, we conclude that bexarotene significantly affects pathways involved in neuronal differentiation and neurite morphology and these functional categories were chosen for further validation.

Bexarotene facilitates the commitment of mouse ES cells to neuronal lineage and facilitates neuronal proliferation and differentiation

Fate determination and proliferation of neuronal progenitors

First, we investigated whether the activation of RXR by bexarotene affects cell/neuronal fate determination of ES cells treated at the stage of EB cell aggregates (Bibel et al., 2004; Fig. 1). To ensure that there was a transition to neuronal lineage, we analyzed the expression of markers specific for neuronal progenitors: Nes, Pax6, and Fabp7. The results shown in Figure $5 A$ demonstrate a dose-dependent effect of bexarotene on Pax 6 and Fabp7 expression level and a statistically significant increase of Nes mRNA. These data suggest that bexarotene affects the generation and the proliferation of neural progenitors from undifferentiated ES cells.

\section{Neural progenitor cell differentiation}

Gene expression levels. To examine the effect of bexarotene on the differentiation of the neural progenitor cells (NPCs), we analyzed the expression of marker-genes specific for differentiating neurons: $T u b b 3$, a microtubule element of the tubulin family found almost exclusively in neurons; vGlut1, a vesicle bound transporter associated with the membranes of synaptic vesicles; Syp, a membrane protein of small synaptic vesicles; and APP. The expression of these markers was examined on days 4 and 10 after the start of treatment, when neural progenitors were expected to differentiate. As seen in Figure 5, B and C, except for $v G l u t 1$ at 0.5 $\mu \mathrm{M}$ bexarotene treatment, the expression of Tubb3, Syp, and $v$ Glut1 was significantly increased on day 4 and continued to increase until day 10 after treatment. In contrast, APP was increased only after day 10 after treatment. Because the Notch1 pathway was identified by ChIP seq and RNA-Seq as RXR targeted, we also examined the level of APP and its proteolytic fragments in mature primary neurons (DIV10) by Western blotting and found no effect (data not shown). This suggests that the effect on APP mRNA is seen only during the transition state between neuronal precursors and immature neurons, not in postmitotic mature neurons. Because Syp was one of the genes with the highest fold change at day 10, we also measured whether bexarotene affects its protein level. As seen from Figure 5D, SYP protein level was barely detectable in the control and its amount was significantly increased in response to bexarotene application.

Marker visualization. To confirm these results and to identify the developing neuronal population morphologically, we performed a double immunostaining on day 10 cells ( $6 \mathrm{~d}$ after plating; Fig. 1). We visualized two markers that are specific for neurons, DCX and MAP2, both of which are expressed in devel- 
A
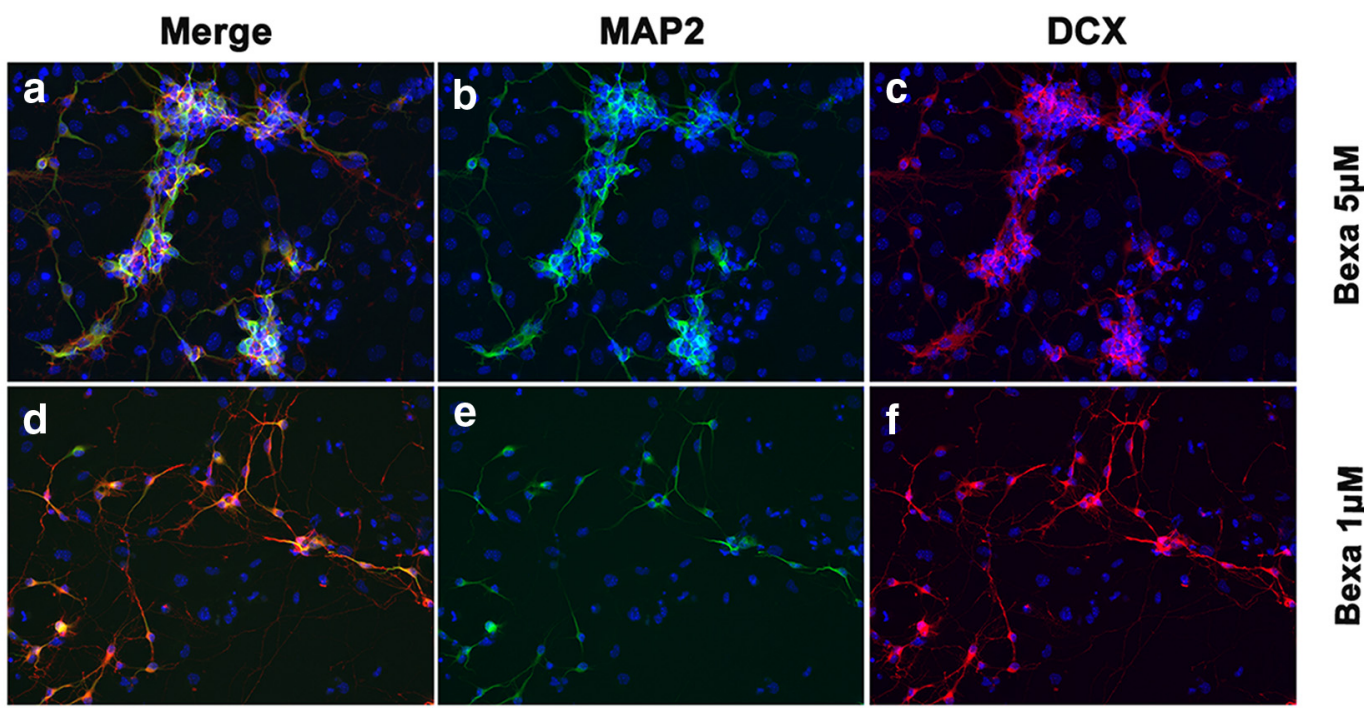

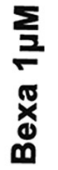

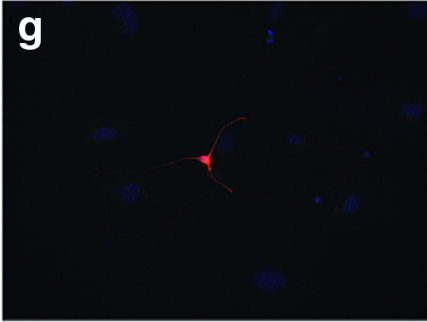

h
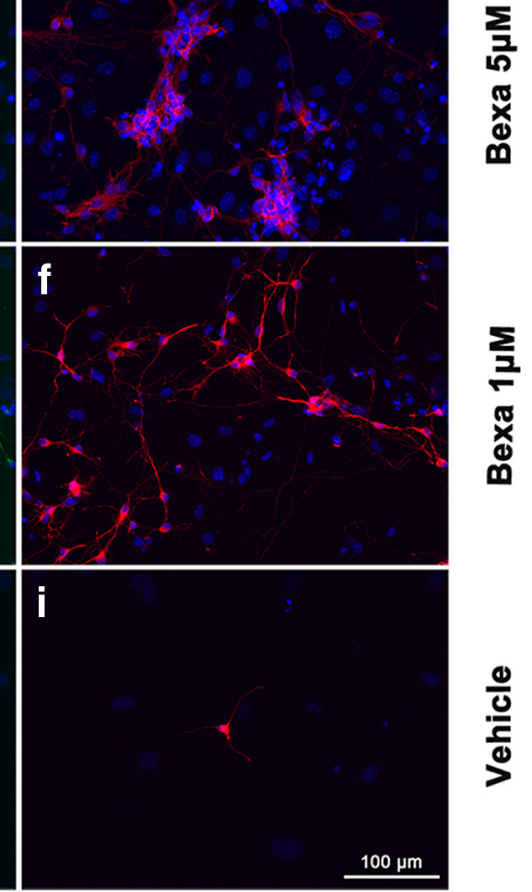

B

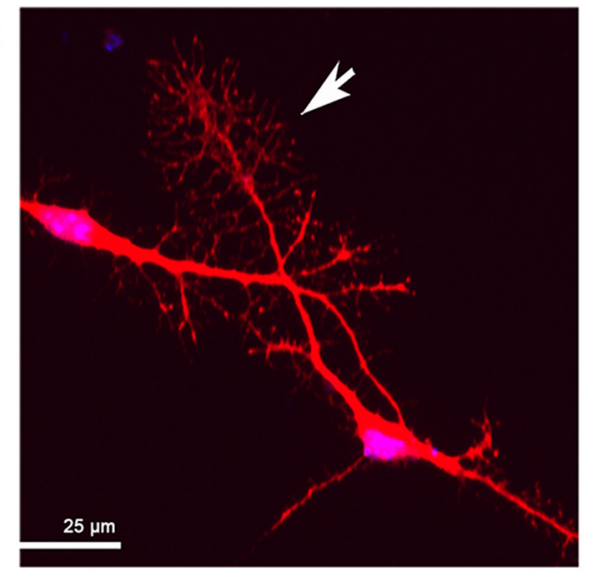

\section{Bexa effect on neuronal differentiation}

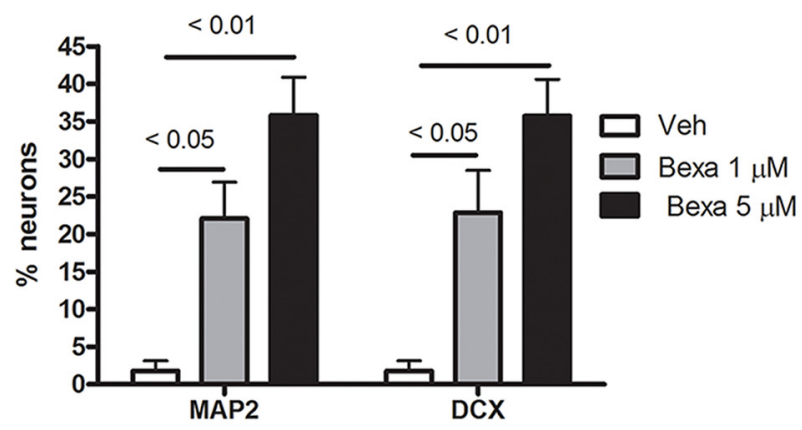

Figure 6. Bexarotene increases neuronal differentiation in a dose-dependent manner in ES cells. ES cell were treated with 1 or $5 \mu \mathrm{m}$ bexarotene for $4 \mathrm{~d}$ and neuronal differentiation was examined $6 \mathrm{~d}$ after plating (day 10). Control cells were treated with vehicle and processed in the same way. $\boldsymbol{A}$, Cells were immunostained with an antibodies against DCX (Ac, $\boldsymbol{A f}, \boldsymbol{A i}$, red) and MAP2 (Ab, $\boldsymbol{A e}, \boldsymbol{A h}$, green). The nuclei were stained with $\mathrm{H} 33342$ (in blue). $\boldsymbol{A a}, \boldsymbol{A d}$, and $\boldsymbol{A g}$ represent merged images of DCX, MAP2, and staining for nuclei, respectively. Scale bar, $100 \mu \mathrm{m}$. $\boldsymbol{B}$, Image of a growth cone. Scale bar, $25 \mu \mathrm{m}$. C, Graphs showing the percentage of neurons in each condition calculated as described in the Materials and Methods. Statistical analyses were by one-way ANOVA ( $p<0.0001$ for MAP2 and DCX) Tukey's posttest values are shown on the graph. The percentage of neurons in vehicle ((DCX, MAP2: 1.8\%); $1 \mu \mathrm{m}$ bexarotene (DCX: $22.9 \%$, MAP2: $22.1 \%)$, and $5 \mu \mathrm{m}$ bexarotene (DCX: 35.7\%, MAP2: 35.8\%) are shown.

oping and migrating neurons (Knoth et al., 2010). We found that these two markers were located in the same neuronal population, although MAP2 was localized to the dendrites and DCX was distributed to all neurites. The distribution of these two markers allowed for a better view of neuron morphology (Fig. 6A), including visualization of DCX-immunostained growth cones (Fig. $6 B)$. The effect of bexarotene on growth cones also suggests an effect on axonal outgrowth. As seen in Figure $6 C$, in vehicletreated control samples, the number of DCX + and MAP2 + neurons was very low and dramatically increased after treatment with bexarotene. Furthermore, there was a significant increase in the number of neurons with increasing bexarotene concentrations and therefore an increased average proportion of double-stained neurons, confirming the dose-dependent effect of bexarotene on neuronal differentiation. Collectively, these results confirm that bexarotene treatment increases the proliferation and the differentiation of neuronal progenitors and axonal growth.

\section{Bexarotene increases the number of BrdU cells in the DG of} APOE3 and APOE4 mice

To determine whether bexarotene enhances the number of progenitors in the adult DG, we treated young ( 2 months old, male and female) APOE3 and APOE4 mice with bexarotene or vehicle for $7 \mathrm{~d}$ and injected BrdU on the last day of the treatment. We counted the 
A
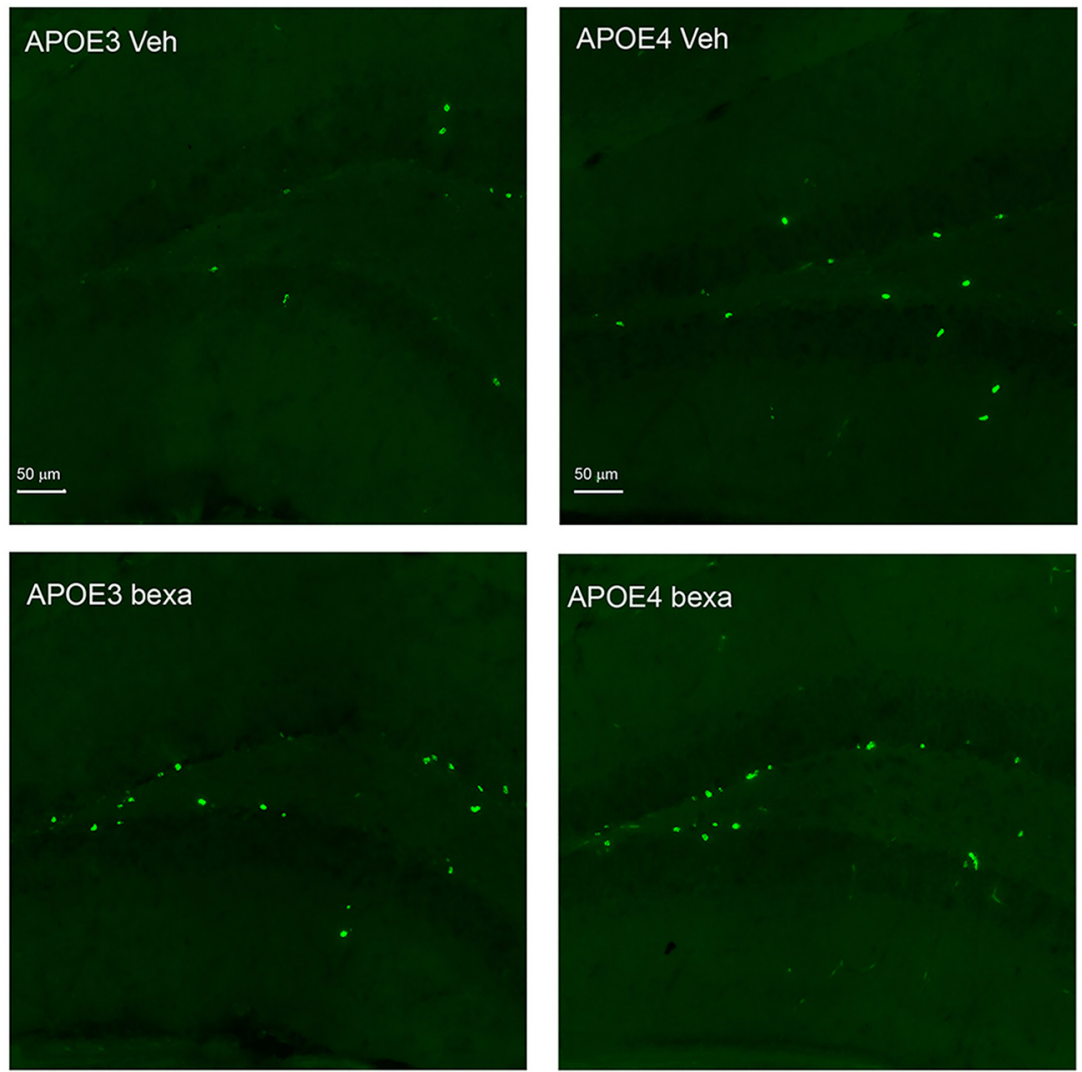

B

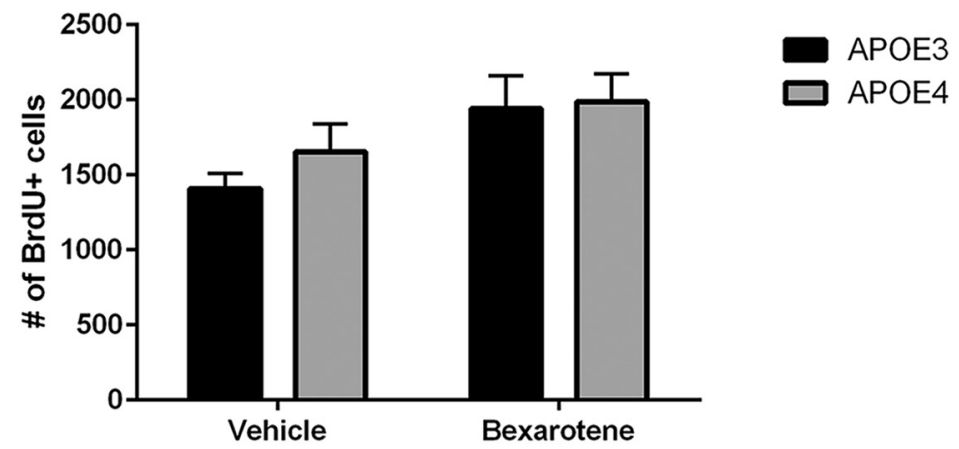

Figure 7. Bexarotene increases the number of BrdU + cells in the DG of APOE 3 and APOE4 mice. Two-month-old APOE3 and APOE4 mice were treated with bexarotene or vehicle for $7 \mathrm{~d}$ and injected with BrdU on the last day of the treatment. The number of BrdU + cells was counted 1 week after BrdU injection. A, Representative images from APOE3 and APOE4 mice treated with bexarotene or vehicle. BrdU + cells are stained in green. Images were taken using the EDF module in NIS elements (Nikon). Scale bars, $50 \mu \mathrm{m}$. B. Analysis by two-way ANOVA with bexarotene treatment and APOE genotype as variables. There was no interaction between treatment and genotype $\left(F_{(1,24)}=0.33 ; p=0.57\right)$, a significant main effect of bexarotene treatment $\left(F_{(1.24)}=5.95\right.$, $p=0.022)$, and no main effect of APOE genotype $\left(F_{(1,24)}=0.6 ; p=0.42\right)$. APOE3, $n=6-7$ male and female mice per group; APOE $4, n=7-8$ male and female mice per group.

number of BrdU+ cells 1 week after BrdU injection. Bexarotene appeared to have an effect on the proliferation of neural progenitors as assessed by the total number of BrdU+ cells (Fig. 7). Analysis by two-way ANOVA demonstrated that there was no interaction between treatment and genotype; however, there was a significant main effect of bexarotene treatment $\left(F_{(1.24)}=5.95, p=0.022\right)$ and no significant main effect of APOE genotype $\left(F_{(1,24)}=0.6 ; p=0.42\right)$.

\section{RXR activation enhances neurite branching and dendritic complexity in primary neurons in vitro}

To determine the effects of RXR activation on dendritic morphology in mature postmitotic neurons, we used primary neuro- nal cultures established from cortices and hippocampi of E18 rat embryos. The cells were infected with GFP-Lentivirus at plating (DIV0) and treated with either vehicle or $1 \mu \mathrm{M}$ bexarotene at DIV4 for $24 \mathrm{~h}$. At DIV11, $6 \mathrm{~d}$ after this transient RXR activation, the GFP+ neurons were fixed (Figs. 8A,B), morphologies digitally reconstructed with Neuromantic (Myatt et al., 2012; Fig. $8 C, D$ ), and morphometric data compared between the two treatment groups. Bexarotene-treated neurons had a manifestly increased number of branch intersections far from the soma as revealed by Sholl analysis (Fig. 8E). The total neurite length showed a strong trend toward increase, but the result was not statistically significant (Fig. 8F). Consistent with the different Sholl profile, both the number of bifurcations (Fig. $8 G$ ) and the number of branches (Fig. 8H) were increased in neurons treated with bexarotene. These data, together with our RNA-Seq and ChIP-Seq data, suggest that bexarotene could have an important effect on neurite branching and complexity in mature neurons, possibly through increased RXR binding to genes involved in these processes.

\section{Bexarotene treatment significantly} improves the dendritic morphology in the CA1 region of the hippocampus of APOE4 Mice

APOE has been shown to stimulate neurite outgrowth in an isoform-specific manner in several cell-based (Holtzman et al., 1995; DeMattos et al., 1998; Dumanis et al., 2009; Hussain et al., 2013) and transgenic mouse models (Holtzman et al., 1995; Ji et al., 2003; Rodriguez et al., 2013). To investigate the effect of bexarotene on the dendritic architecture of pyramidal hippocampal neurons in the CA1 region, we used mice expressing APOE3 and APOE4. In the control mice (vehicle-treated), examination of dendrites of APOE4 mice revealed a significant decrease in dendritic length (Fig. 9B), number of branches (Fig. 9D), and segments (Fig. 9C) compared with APOE3 mice (Fig. $9 A$, cf. APOE3-veh, APOE4-veh). The data suggest that the APOE4 isoform affects neuronal architecture and confirm previous data (Dumanis et al., 2009). Bexarotene treatment, however, restored the dendritic morphology in CA1 of APOE4 mice to that of APOE3-expressing mice (Fig. 9A, cf. APOE3bexa, APOE4-bexa). Bexarotene treatment did not affect neurite structure in APOE3 mice. Normalized data revealed no significant change in the numbers of counted nuclei in the CA1 region of the hippocampus regardless of APOE genotype or treatment. The results demonstrate that bexarotene improves compromised dendritic morphology in mice expressing the human APOE4 isoform. 

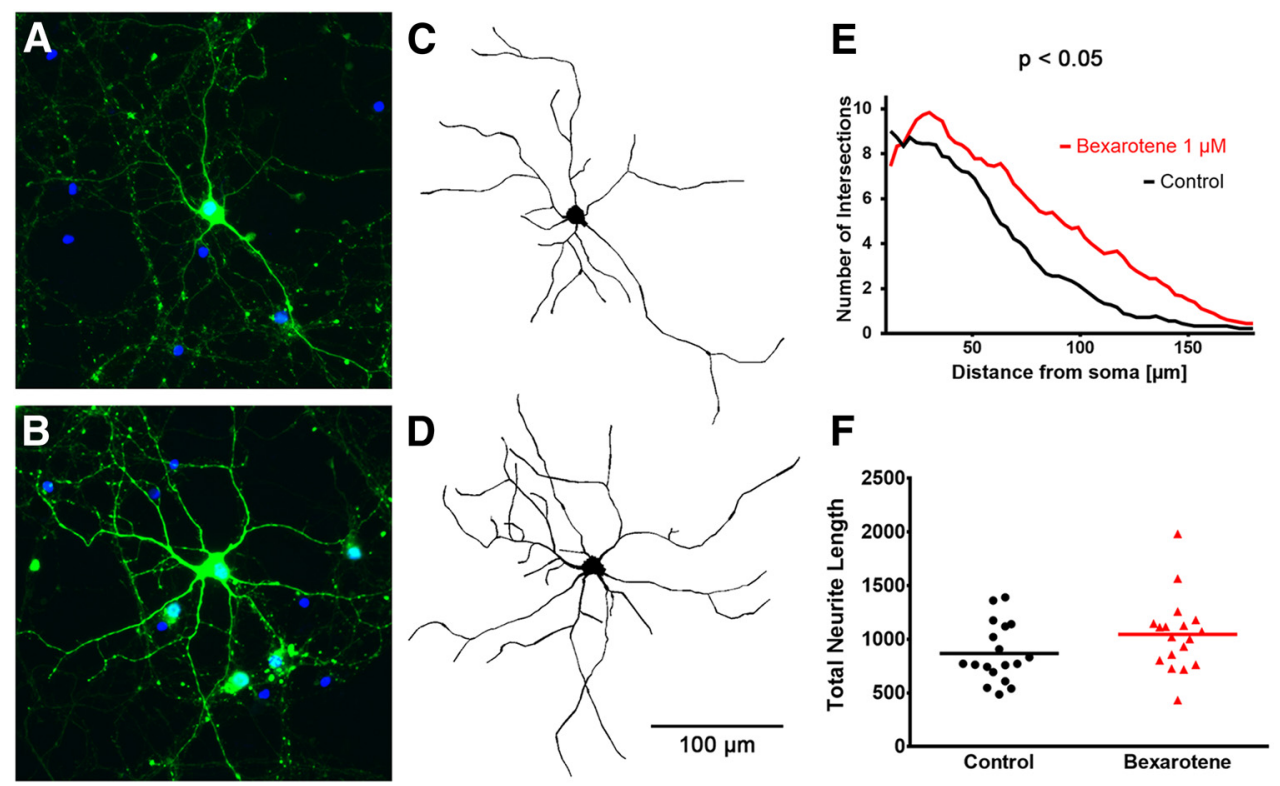

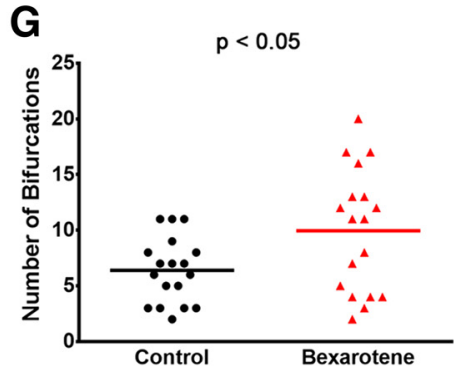

H

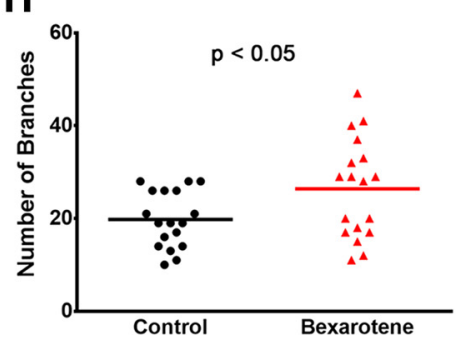

Figure 8. Bexarotene enhances neurite branching and affects dendrite complexity in primary neurons. Primary rat neurons were infected with GFP expressing lentivirus at DIV0 and treated with bexarotene or vehicle at DIV4 for $24 \mathrm{~h}$. Sholl analysis was performed $6 \mathrm{~d}$ later at DIV11. $A, \boldsymbol{B}$, Photomicrographs showing the morphology of DIV11 GFP + neurons treated either with vehicle $(\boldsymbol{A})$ or $1 \mu \mathrm{m}$ bexarotene $(\boldsymbol{B})$. $\boldsymbol{C}, \boldsymbol{D}$, Digital reconstructions of the cells in $\boldsymbol{A}$ and $\boldsymbol{B}$ are shown in $\boldsymbol{C}$ and $\boldsymbol{D}$, respectively. $\boldsymbol{E}$, Bexarotene-treated neurons exhibit distinct Sholl profiles with an increased number of branch intersections far from the soma. $\boldsymbol{F}$, Clearly visible trend toward an increased total neurite length, which did not reach statistical significance. $\mathbf{G}, \boldsymbol{H}$, Consistent with the differing Sholl profile, both the number of bifurcations $(\boldsymbol{G})$ and the number of branches $(\boldsymbol{H})$ were increased in the neurons treated with bexarotene. For each treatment group, images were taken from at least nine wells and more than two GFP + neurons per well.

\section{Discussion}

The objective of this study was to determine pathways affected by the RXR agonist bexarotene in the brain that could provide an explanation for the improvement of behavior deficits in mice expressing human APP (Cramer et al., 2012; Fitz et al., 2013; Tesseur et al., 2013) or mouse APP (McFarland et al., 2013; Boehm-Cagan and Michaelson, 2014). To address this question and to reveal genome-wide changes in the RXR cistrome (ChIPSeq) and gene expression profile (RNA-Seq) in response to bexarotene treatment, we used an unbiased approach: highthroughput massive parallel sequencing. We show that, in both datasets, bexarotene-liganded RXR affected signaling pathways involved in functional categories such as "neuron projection development" and "neuronal differentiation." To further validate the significance of RXR for these pathways, we used ES cells, primary neurons, and APOE 3 and APOE4 mice for bexarotene treatment. The results confirmed that bexarotene-activated RXRs have a role in neuronal development at different levels, including adoption of neuronal cell fate, neuronal proliferation and differentiation, and stimulated neurite outgrowth. In addition, the results of our in vivo experiments with APOE3 and APOE4 mice support the idea that, in response to bexarotene, activated RXRs increased adult neurogenesis and restored the compromised dendritic morphology in APOE4 mice. Some important conclusions can be drawn from these data.

First, the list of RXR targets differentially affected by bexarotene includes genes involved in the neurogenesis, migration, and maturation of adult born neurons, as well as other genes that could affect the morphology of mature neurons. A critical role for RXRs in CNS development and differentiation was suggested at the time the receptors were cloned (Mangelsdorf et al., 1992). The question is whether any of these processes can account for the improved behavior outcomes by bexarotene treatment (Cramer et al., 2012; Fitz et al., 2013; McFarland et al., 2013). Apart from some controversy, most of the studies have demonstrated that adult neurogenesis, particularly the adult neurons born in the DG, improve the behavior deficits in rodents (for review, see Lepousez et al., 2015), especially for demanding tasks such as fear conditioning and radial maze paradigms (Clelland et al., 2009; Sahay et al., 2011). The effect of bexarotene effect on different stages of neurogenesis was found in ES cells in vitro and on the proliferation of BrdU-labeled neuronal precursors in APOE mice. Although an effect on commitment to cell fate with a role in behavior paradigms in adult mice is less probable, the effect of bexarotene on neuronal differentiation or on neuronal projections could be of significance for such outcomes. It was not the goal of this study to examine specifically at which exact stage of adult neurogenesis bexarotene is most effective in vivo. However, it is important to note that the list of differentially affected genes includes RXR targets that could affect both adult neurogenesis and the morphology of postmitotic mature neurons. The latter could be of significance, even after a short treatment, for neuronal complexity repair following injury, as well as in response to toxic effects of $\mathrm{A} \beta$ oligomers or deposits. Examining the gene list in categories such as "neuron projection development" and "behavior," we found RXR targets that could play roles at different stages of adult neurogenesis including migration, axonal growth, and development of dendrites in newborn neurons and in mature neurons. For example, ChIP-Seq and RNA-Seq data revealed that bexarotene affected Notch1 signaling known to be essential, not only in cell fate decisions in uncommitted proliferating cells (Artavanis-Tsakonas and Simpson, 1991), but also in the differentiation of immature neurons (Redmond et al., 2000), as well as in postmitotic mature neurons for synaptic remodeling or neurite extension/retraction (Sestan et al., 1999). Interestingly, in another study using an RNA-Seq approach, we found that Notch1 and Notch 2 were significantly upregulated by bexarotene in cortex of APOE3 mice (K. N. Nam, A. Mounier, J. Schug, I. Lefterov, 
A
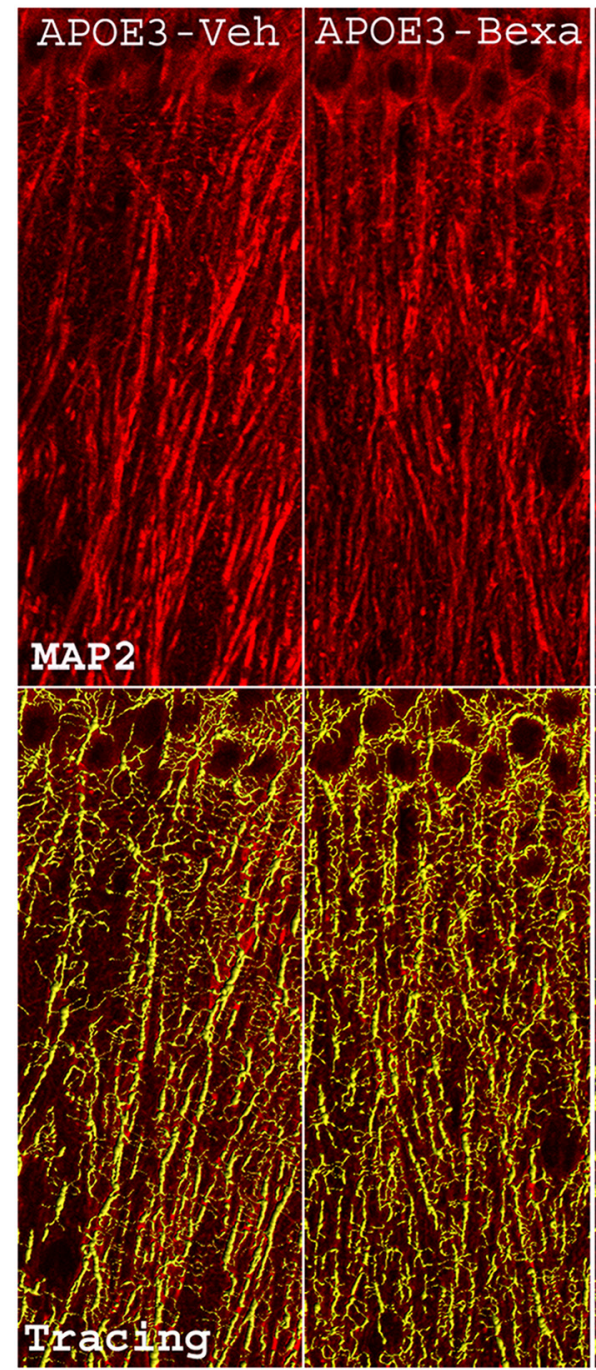
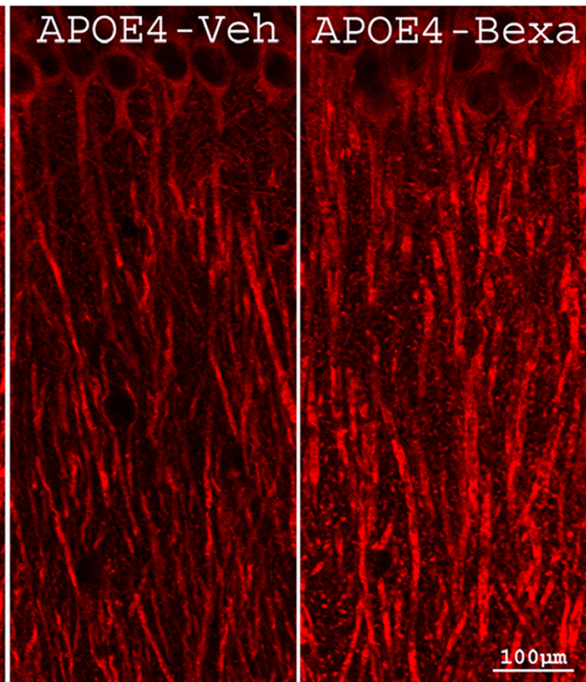

B

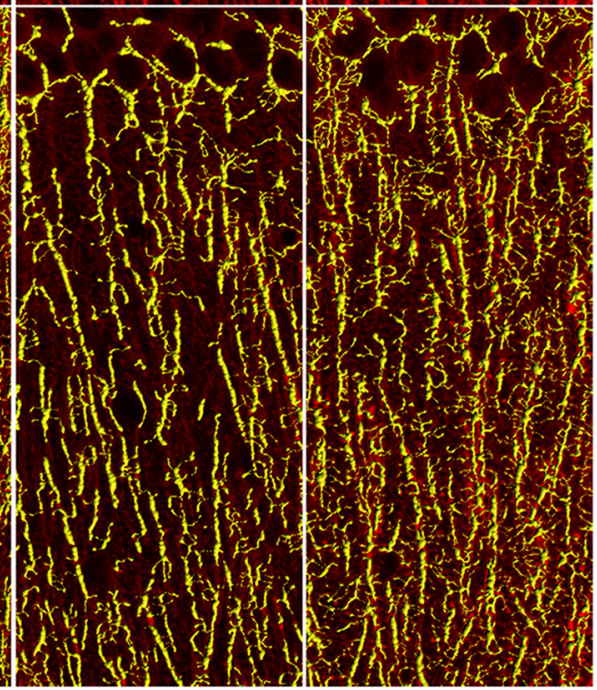

Dendritic length

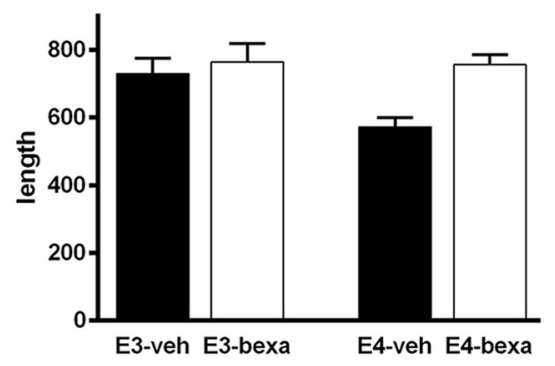

C Number of dendritic segments

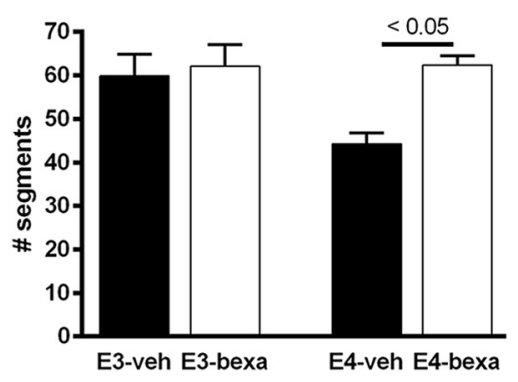

D Number of branches

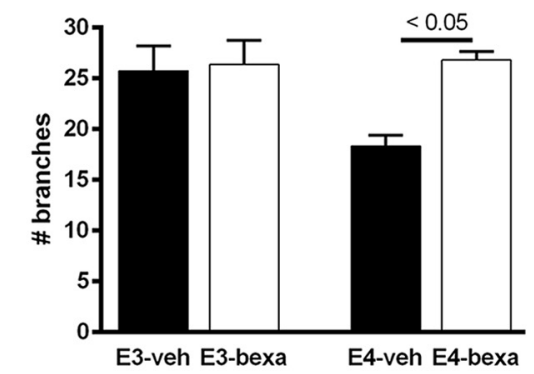

Figure 9. Bexarotene restores dendritic morphology of the CA1 region of the hippocampus of APOE4 mice. $\boldsymbol{A}$, Representative images of MAP2 staining and dendritic tree reconstruction in the hippocampal CA1 region using Imaris filament tracing software ( $60 \times$ confocal imaging). A total of four images are shown for each of the four sections for each mouse. $n=3$ male and female mice per group. The total dendritic length $(\boldsymbol{B})$, branch points $(\boldsymbol{C})$, and segments $(\boldsymbol{D})$ were quantified using Imaris filament tracing macros and normalized to the total $\mathrm{H} 33342+$ nuclei of the $\mathbf{C A} 1$ region. Note that APOE4 vehicle-treated mice display significantly diminished dendritic length, branch points, and segments compared with APOE3 vehicle-treated mice and this characteristic was reversed by bexarotene treatment. Analysis by one-way ANOVA with Tukey's posttest, $p<0.05$.

and R. Koldamova, unpublished data). Additional genes associated with the Notch1 pathway in the current datasets include Dlk1, which acts as an inhibitor of Notch1 (Falix et al., 2012), Nerve growth factor receptor (Ngfr; Chan et al., 2013), and Epidermal growth factor receptor (Egfr; Aguirre et al., 2010). Other RXR targets that could be involved in both neurogenesis and neurite growth are the Nogo receptors Rnt4r (nogo-66/Reticulon 4 receptor) and its homolog Rtn4rll. Nogo receptors and pathway inhibit neurite and axonal growth in vitro, inhibit neurite regeneration of adult CNS neurons after traumatic injuries, and even modulate $\mathrm{A} \beta$ secretion (David et al., 2008; Xiao et al., 2012). Bexarotene increased RXR enrichment to Rtn $4 r l 1$ (as revealed by ChIP-Seq data) and the expression of its homolog Rtn4r was found to be significantly decreased by the drug (RNA-Seq and qPCR shown in Fig. 3B-D). Published data also suggest a role for Rtn $4 r$ in inflammation, specifically in the phagocytosis by macrophages (David et al., 2008). Interestingly, recent studies from us and from other groups implicated bexarotene-activated RXR in $\mathrm{A} \beta$ phagocytosis by microglia (Lefterov et al., 2015; Savage et al., 2015). Other RXR targets significant for those processes are Nrp2 (Neuropilin 2), Erbb4, and Ptpro, which we have already mentioned in the Results section (Shintani et al., 2006; Miao and Wang, 2012). Neuropilins are receptors for class 3 semaphorins and regulate the development of dendrites of the newborn neurons in hippocampus (Ng et al., 2013). Erbb4 (erb-b2) is a receptor tyrosine kinase that affects spine density in cortex of ErbB4 conditional knock-out mice (Cooper and Koleske, 2014) and is important in the fear conditioning paradigm (Lu et al., 2014).

Second, because "regulation of transcription" is a highly significant GO term in the ChIP-Seq dataset, some of the bexarotene-induced effects may well be secondary to upregulated transcription factors with established roles in neuronal differentiation and neurogenesis. As already mentioned, there was an increased RXR binding to Notch1 and other transcription factors such as Barhl2 and Emxl identified by ChIP-Seq and RNA-Seq (discussed in the Results). Other examples are Bcl11b/Ctip2, a transcription factor expressed in postmitotic neurons with a critical role during postnatal development of the DG (Simon et al., 
2012). Some of these RXR targets were validated by qPCR in brain samples or ES cells, confirming the results of genome-wide analyses (Fig. $3 C, D$ ). It should be noted also that it is difficult to ascribe all of the effects to genes regulated primarily by RXR homodimers. RXR/RAR heterodimers are usually considered nonpermissive, but in a cell- and tissue-specific environment, they may be partially permissive even for a highly specific agonist such as bexarotene (Blomhoff and Blomhoff, 2006; Daniel et al., 2014). Furthermore, LXRs and PPAR $\gamma$ can operate only as obligate permissive heterodimers with RXR and, therefore, bexarotene-induced phenotypic effects could be mediated by RXR-LXR- or RXR-PPAR $\gamma$-permissive heterodimers (Sacchetti et al., 2009; Sun and Shi, 2010).

Third, we should consider that activated RXR could also affect local chromatin architecture orchestrated primarily by histone acetylases, deacetylases, methyltransferases, and demethylases, controlling distinct modifications of histone marks indicative of transcriptional activity or silencing. In our ChIP-Seq data, we identified a strong binding of RXR to the histone demethylase $K d m 6 b / J M J D 3$ (Fig. 2B). Kdm6b is attracting attention because of its role in Polycomb Repressive Complex 2 (PRC2)-mediated changes in chromatin structure (Li et al., 2014a; Tang et al., 2014). Kdm6b was shown to be involved in neurogenic programs in several studies (Jepsen et al., 2007; Fonseca et al., 2012). Interestingly, Kdm6b interacts with NK2 homeobox 1, which is differentially affected by bexarotene in our RNA-Seq dataset (Nkx2.1, $\mathrm{FC}=6.5$-fold; FDR $=0.002$ ) and regulates its expression ( $\mathrm{Li}$ et al., 2014a), as well as the expression of other RXR targets involved in neuronal differentiation or neuritogenesis, such as Dlk1 (Gao et al., 2015) and Egfr (Shaw and Martin, 2009). In addition, we identified an increased enrichment of bexarotene-activated RXR in vicinity of Hdac2 (histone deacetylase 2; Fig. $2 D, E$ ) and, although its mRNA was not differentially affected, a few other histone deacetylases, namely Hdac7 and Hdac10, were significantly downregulated by bexarotene ( $\sim 2$-fold). In general, lysine acetylation of histone proteins is a key epigenetic modulator of gene expression and controls numerous biological processes. It is regulated by the interplay of lysine acetyltransferases (KATs) and histone deacetylases (HDACs) and affects synaptic activity and cognition (Peleg et al., 2010; Cronican et al., 2013; Penney and Tsai, 2014).

Finally, we have recently performed RNA-Seq on bexarotenetreated APP-transgenic mice (expressing mouse Apoe), which demonstrated that the most affected categories were immunity and inflammation (Lefterov et al., 2015). Although we cannot compare the two datasets directly (the model used in this study expresses human APOE4 and mouse App), it is reasonable to assume that the development of an amyloid phenotype significantly changes the transcriptome in APP-transgenic mice and can potentially affect RXR binding to genomic sites. A recent study demonstrated significant changes in the transcriptional profile during the transition toward neurodegeneration, probably as a result of epigenetic changes (Gjoneska et al., 2015). Similarly, we can expect differences in the transcriptional profile of mice expressing human APOE3 versus mice expressing APOE4 isoform.

In conclusion, our data demonstrate that bexarotene-activated RXRs promote genetic programs that could have significance for cognitive performance in APOE4 mice.

\section{References}

Aguirre A, Rubio ME, Gallo V (2010) Notch and EGFR pathway interaction regulates neural stem cell number and self-renewal. Nature 467:323-327. CrossRef Medline
Akama K, Horikoshi T, Nakayama T, Otsu M, Imaizumi N, Nakamura M, Toda T, Inuma M, Hirano H, Kondo Y, Suzuki Y, Inoue N (2013) Proteomic identification of differentially expressed genes during differentiation of cynomolgus monkey (Macaca fascicularis) embryonic stem cells to astrocyte progenitor cells in vitro. Biochim Biophys Acta 1834:601-610. CrossRef Medline

Artavanis-Tsakonas S, Simpson P (1991) Choosing a cell fate: a view from the Notch locus. Trends Genet 7:403-408. Medline

Bales KR, Liu F, Wu S, Lin S, Koger D, DeLong C, Hansen JC, Sullivan PM, Paul SM (2009) Human APOE isoform-dependent effects on brain beta-amyloid levels in PDAPP transgenic mice. J Neurosci 29:6771-6779. CrossRef Medline

Bibel M, Richter J, Schrenk K, Tucker KL, Staiger V, Korte M, Goetz M, Barde YA (2004) Differentiation of mouse embryonic stem cells into a defined neuronal lineage. Nat Neurosci 7:1003-1009. CrossRef Medline

Bibel M, Richter J, Lacroix E, Barde YA (2007) Generation of a defined and uniform population of CNS progenitors and neurons from mouse embryonic stem cells. Nat Protoc 2:1034-1043. CrossRef Medline

Blomhoff R, Blomhoff HK (2006) Overview of retinoid metabolism and function. J Neurobiol 66:606-630. CrossRef Medline

Boehm-Cagan A, Michaelson DM (2014) Reversal of apoE4-driven brain pathology and behavioral deficits by bexarotene. J Neurosci 34:72937301. CrossRef Medline

Boergesen M, Pedersen TÅ, Gross B, van Heeringen SJ, Hagenbeek D, Bindesbøll C, Caron S, Lalloyer F, Steffensen KR, Nebb HI, Gustafsson JA, Stunnenberg HG, Staels B, Mandrup S (2012) Genome-wide profiling of liver $\mathrm{X}$ receptor, retinoid $\mathrm{X}$ receptor, and peroxisome proliferatoractivated receptor alpha in mouse liver reveals extensive sharing of binding sites. Mol Cell Biol 32:852-867. CrossRef Medline

Bomben V, Holth J, Reed J, Cramer P, Landreth G, Noebels J (2014) Bexarotene reduces network excitability in models of Alzheimer's disease and epilepsy. Neurobiol Aging 35:2091-2095. CrossRef Medline

Bulfone A, Menguzzato E, Broccoli V, Marchitiello A, Gattuso C, Mariani M, Consalez GG, Martinez S, Ballabio A, Banfi S (2000) Barhll, a gene belonging to a new subfamily of mammalian homeobox genes, is expressed in migrating neurons of the CNS. Hum Mol Genet 9:1443-1452. CrossRef Medline

Cecchi C, Boncinelli E (2000) Emx homeogenes and mouse brain development. Trends Neurosci 23:347-352. CrossRef Medline

Chan AA, Hertsenberg AJ, Funderburgh ML, Mann MM, Du Y, Davoli KA, Mich-Basso JD, Yang L, Funderburgh JL (2013) Differentiation of human embryonic stem cells into cells with corneal keratocyte phenotype. PLoS One 8:e56831. CrossRef Medline

Chen Y, Durakoglugil MS, Xian X, Herz J (2010) ApoE4 reduces glutamate receptor function and synaptic plasticity by selectively impairing ApoE receptor recycling. Proc Natl Acad Sci U S A 107:12011-12016. CrossRef Medline

Claudel T, Leibowitz MD, Fiévet C, Tailleux A, Wagner B, Repa JJ, Torpier G, Lobaccaro JM, Paterniti JR, Mangelsdorf DJ, Heyman RA, Auwerx J (2001) Reduction of atherosclerosis in apolipoprotein E knockout mice by activation of the retinoid X receptor. Proc Natl Acad Sci U S A 98: 2610-2615. CrossRef Medline

Clelland CD, Choi M, Romberg C, Clemenson GD Jr, Fragniere A, Tyers P, Jessberger S, Saksida LM, Barker RA, Gage FH, Bussey TJ (2009) A functional role for adult hippocampal neurogenesis in spatial pattern separation. Science. 325:210-213. CrossRef Medline

Cooper MA, Koleske AJ (2014) Ablation of ErbB4 from excitatory neurons leads to reduced dendritic spine density in mouse prefrontal cortex. J Comp Neurol 522:3351-3362. CrossRef Medline

Cramer PE, Cirrito JR, Wesson DW, Lee CY, Karlo JC, Zinn AE, Casali BT, Restivo JL, Goebel WD, James MJ, Brunden KR, Wilson DA, Landreth GE (2012) ApoE-directed therapeutics rapidly clear beta-amyloid and reverse deficits in $\mathrm{AD}$ mouse models. Science 335:1503-1506. CrossRef Medline

Cronican AA, Fitz NF, Carter A, Saleem M, Shiva S, Barchowsky A, Koldamova R, Schug J, Lefterov I (2013) Genome-wide alteration of histone $\mathrm{H} 3 \mathrm{~K} 9$ acetylation pattern in mouse offspring prenatally exposed to arsenic. PLoS One 8:e53478. CrossRef Medline

Cuntz H, Forstner F, Borst A, Häusser M (2011) The TREES toolbox-probing the basis of axonal and dendritic branching. Neuroinformatics 9: 91-96. CrossRef Medline

Daniel B, Nagy G, Hah N, Horvath A, Czimmerer Z, Poliska S, Gyuris T, 
Keirsse J, Gysemans C, Van Ginderachter JA, Balint BL, Evans RM, Barta E, Nagy L (2014) The active enhancer network operated by liganded RXR supports angiogenic activity in macrophages. Genes Dev 28:15621577. CrossRef Medline

David S, Fry EJ, López-Vales R (2008) Novel roles for Nogo receptor in inflammation and disease. Trends Neurosci 31:221-226. CrossRef Medline

DeMattos RB, Curtiss LK, Williams DL (1998) A minimally lipidated form of cell-derived apolipoprotein E exhibits isoform-specific stimulation of neurite outgrowth in the absence of exogenous lipids or lipoproteins. J Biol Chem 273:4206-4212. CrossRef Medline

Donkin JJ, Stukas S, Hirsch-Reinshagen V, Namjoshi D, Wilkinson A, May S, Chan J, Fan J, Collins J, Wellington CL (2010) ATP-binding cassette transporter Al mediates the beneficial effects of the liver $\mathrm{X}$ receptor agonist GW3965 on object recognition memory and amyloid burden in amyloid precursor protein/presenilin 1 mice. J Biol Chem 285:34144-34154. CrossRef Medline

Dumanis SB, Tesoriero JA, Babus LW, Nguyen MT, Trotter JH, Ladu MJ, Weeber EJ, Turner RS, Xu B, Rebeck GW, Hoe HS (2009) ApoE4 decreases spine density and dendritic complexity in cortical neurons in vivo. J Neurosci 29:15317-15322. CrossRef Medline

Evans RM, Mangelsdorf DJ (2014) Nuclear Receptors, RXR, and the Big Bang. Cell 157:255-266. CrossRef Medline

Falix FA, Aronson DC, Lamers WH, Gaemers IC (2012) Possible roles of DLK1 in the Notch pathway during development and disease. Biochim Biophys Acta 1822:988-995. CrossRef Medline

Ficenec D, Osborne M, Pradines J, Richards D, Felciano R, Cho RJ, Chen RO, Liefeld T, Owen J, Ruttenberg A, Reich C, Horvath J, Clark T (2003) Computational knowledge integration in biopharmaceutical research. Briefings in Bioinformatics 4:260-278. CrossRef Medline

Fitz NF, Cronican AA, Saleem M, Fauq AH, Chapman R, Lefterov I, Koldamova R (2012) Abcal deficiency affects Alzheimer's disease-like phenotype in human ApoE4 but not in ApoE3-targeted replacement mice. J Neurosci 32:13125-13136. CrossRef Medline

Fitz NF, Cronican AA, Lefterov I, Koldamova R (2013) Comment on "ApoE-directed therapeutics rapidly clear beta-amyloid and reverse deficits in AD mouse models." Science 340:924-c. Medline

Fonseca MB, Nunes AF, Morgado AL, Solá S, Rodrigues CM (2012) TAp63gamma demethylation regulates protein stability and cellular distribution during neural stem cell differentiation. PLoS One 7:e52417. CrossRef Medline

Franklin KBJ, Paxinos G (2007) The mouse brain in stereotaxic coordinates. Amsterdam: Academic.

Gao Y, Han Z, Li Q, Wu Y, Shi X, AiZ, Du J, Li W, Guo Z, Zhang Y (2015) Vitamin $\mathrm{C}$ induces a pluripotent state in mouse embryonic stem cells by modulating microRNA expression. FEBS J 282:685-699. CrossRef Medline

Gjoneska E, Pfenning AR, Mathys H, Quon G, Kundaje A, Tsai LH, Kellis M (2015) Conserved epigenomic signals in mice and humans reveal immune basis of Alzheimer's disease. Nature. 518:365-369. CrossRef Medline

Heneka MT, Sastre M, Dumitrescu-Ozimek L, Hanke A, Dewachter I, Kuiperi C, O'Banion K, Klockgether T, Van Leuven F, Landreth GE (2005) Acute treatment with the PPARgamma agonist pioglitazone and ibuprofen reduces glial inflammation and Abeta1-42 levels in APPV717I transgenic mice. Brain 128:1442-1453. CrossRef Medline

Holtzman DM, Pitas RE, Kilbridge J, Nathan B, Mahley RW, Bu G, Schwartz AL (1995) Low density lipoprotein receptor-related protein mediates apolipoprotein E-dependent neurite outgrowth in a central nervous system-derived neuronal cell line. Proc Natl Acad Sci U S A 92:94809484. CrossRef Medline

Huang da W, Sherman BT, Lempicki RA (2009) Systematic and integrative analysis of large gene lists using DAVID bioinformatics resources. Nat Protoc 4:44-57. Medline

Hussain A, Luong M, Pooley A, Nathan BP (2013) Isoform-specific effects of apoE on neurite outgrowth in olfactory epithelium culture. J Biomed Sci 20:49. CrossRef Medline

Jawed SI, Myskowski PL, Horwitz S, Moskowitz A, Querfeld C (2014) Primary cutaneous T-cell lymphoma (mycosis fungoides and Sezary syndrome): part II. Prognosis, management, and future directions. J Am Acad Dermatol 223.e1-17; quiz 240-2. Medline

Jepsen K, Solum D, Zhou T, McEvilly RJ, Kim HJ, Glass CK, Hermanson O, Rosenfeld MG (2007) SMRT-mediated repression of an H3K27 demethylase in progression from neural stem cell to neuron. Nature 450: 415-419. CrossRef Medline
Jiang Q, Lee CY, Mandrekar S, Wilkinson B, Cramer P, Zelcer N, Mann K, Lamb B, Willson TM, Collins JL, Richardson JC, Smith JD, Comery TA, Riddell D, Holtzman DM, Tontonoz P, Landreth GE (2008) ApoE promotes the proteolytic degradation of Abeta. Neuron 58:681-693. CrossRef Medline

Ji Y, Gong Y, Gan W, Beach T, Holtzman DM, Wisniewski T (2003) Apolipoprotein $\mathrm{E}$ isoform-specific regulation of dendritic spine morphology in apolipoprotein E transgenic mice and Alzheimer's disease patients. Neuroscience 122:305-315. CrossRef Medline

Knoth R, Singec I, Ditter M, Pantazis G, Capetian P, Meyer RP, Horvat V, Volk B, Kempermann G (2010) Murine features of neurogenesis in the human hippocampus across the lifespan from 0 to 100 years. PLoS One 5:e8809. CrossRef Medline

Koldamova RP, Lefterov IM, Ikonomovic MD, Skoko J, Lefterov PI, Isanski BA, DeKosky ST, Lazo JS (2003) 22R-hydroxycholesterol and 9-cisretinoic acid induce ATP-binding cassette transporter Al expression and cholesterol efflux in brain cells and decrease amyloid beta secretion. J Biol Chem 278:13244-13256. CrossRef Medline

Koldamova RP, Lefterov IM, Staufenbiel M, Wolfe D, Huang S, Glorioso JC, Walter M, Roth MG, Lazo JS (2005) The liver X receptor ligand T0901317 decreases amyloid (beta) production in vitro and in a mouse model of Alzheimer's disease. J Biol Chem 280:4079-4088. CrossRef Medline

Koldamova R, Schug J, Lefterova M, Cronican AA, Fitz NF, Davenport FA, Carter A, Castranio EL, Lefterov I (2014) Genome-wide approaches reveal EGR1-controlled regulatory networks associated with neurodegeneration. Neurobiol Dis 63:107-114. CrossRef Medline

Laffitte BA, Repa JJ, Joseph SB, Wilpitz DC, Kast HR, Mangelsdorf DJ, Tontonoz P (2001) LXRs control lipid-inducible expression of the apolipoprotein E gene in macrophages and adipocytes. Proc Natl Acad Sci U S A 98:507-512. CrossRef Medline

Langmead B, Salzberg SL (2012) Fast gapped-read alignment with Bowtie 2. Nat Methods 9:357-359. CrossRef Medline

Lefterov I, Schug J, Mounier A, Nam KN, Fitz NF, Koldamova R (2015) RNA-Sequencing reveals transcriptional up-regulation of Trem2 in response to bexarotene treatment. Neurobiol Dis $82: 132-140$. CrossRef Medline

Lepousez G, Nissant A, Lledo PM (2015) Adult neurogenesis and the future of the rejuvenating brain circuits. Neuron 86:387-401. CrossRef Medline

Li Q, Wang HY, Chepelev I, Zhu Q, Wei G, Zhao K, Wang RF (2014a) Stage-dependent and locus-specific role of histone demethylase Jumonji D3 (JMJD3) in the embryonic stages of lung development. PLoS Genet 10:e1004524. CrossRef Medline

Li Q, Zou J, Wang M, Ding X, Chepelev I, Zhou X, Zhao W, Wei G, Cui J, Zhao K, Wang HY, Wang RF (2014b) Critical role of histone demethylase Jmjd 3 in the regulation of CD4+ T-cell differentiation. Nat Commun 5:5780. CrossRef Medline

Lu Y, Sun XD, Hou FQ, Bi LL, Yin DM, Liu F, Chen YJ, Bean JC, Jiao HF, Liu X, Li BM, Xiong WC, Gao TM, Mei L (2014) Maintenance of GABAergic activity by neuregulin 1-ErbB4 in amygdala for fear memory. Neuron. 84:835-846. CrossRef Medline

Ma T, Chen Y, Vingtdeux V, Zhao H, Viollet B, Marambaud P, Klann E (2014) Inhibition of AMP-activated protein kinase signaling alleviates impairments in hippocampal synaptic plasticity induced by amyloid beta. J Neurosci 34:12230-12238. CrossRef Medline

Mangelsdorf DJ, Ong ES, Dyck JA, Evans RM (1990) Nuclear receptor that identifies a novel retinoic acid response pathway. Nature 345:224-229. CrossRef Medline

Mangelsdorf DJ, Borgmeyer U, Heyman RA, Zhou JY, Ong ES, Oro AE, Kakizuka A, Evans RM (1992) Characterization of three RXR genes that mediate the action of 9-cis retinoic acid. Genes Dev 6:329-344. CrossRef Medline

McFarland K, Spalding TA, Hubbard D, Ma JN, Olsson R, Burstein ES (2013) Low dose bexarotene treatment rescues dopamine neurons and restores behavioral function in models of Parkinson's disease. ACS Chem Neurosci 4:1430-1438. CrossRef Medline

Miao H, Wang B (2012) EphA receptor signaling-complexity and emerging themes. Semin Cell Dev Biol. 23:16-25. CrossRef Medline

Myatt DR, Hadlington T, Ascoli GA, Nasuto SJ (2012) Neuromantic - from semi-manual to semi-automatic reconstruction of neuron morphology. Front Neuroinform 6:4. Medline

Ng T, Ryu JR, Sohn JH, Tan T, Song H, Ming GL, Goh EL (2013) Class 3 
semaphorin mediates dendrite growth in adult newborn neurons through Cdk5/FAK pathway. PLoS One 8:e65572. CrossRef Medline

Ngwenya LB, Peters A, Rosene DL (2005) Light and electron microscopic immunohistochemical detection of bromodeoxyuridine-labeled cells in the brain: different fixation and processing protocols. J Histochem Cytochem 53:821-832. CrossRef Medline

Ottaviani S, de Giorgio A, Harding V, Stebbing J, Castellano L (2014) Noncoding RNAs and the control of hormonal signaling via nuclear receptor regulation. J Mol Endocrinol 53:R61-R70. CrossRef Medline

Peleg S, Sananbenesi F, Zovoilis A, Burkhardt S, Bahari-Javan S, Agis-Balboa RC, Cota P, Wittnam JL, Gogol-Doering A, Opitz L, Salinas-Riester G, Dettenhofer M, Kang H, Farinelli L, Chen W, Fischer A (2010) Altered histone acetylation is associated with age-dependent memory impairment in mice. Science. 328:753-756. CrossRef Medline

Penney J, Tsai LH (2014) Histone deacetylases in memory and cognition. Sci Signal 7:re12. CrossRef Medline

Penton AL, Leonard LD, Spinner NB (2012) Notch signaling in human development and disease. Semin Cell Dev Biol. 23:450-457. CrossRef Medline

Price AR, Xu G, Siemienski ZB, Smithson LA, Borchelt DR, Golde TE, Felsenstein KM (2013) Comment on "ApoE-directed therapeutics rapidly clear beta-amyloid and reverse deficits in AD mouse models." Science 340:924-d. Medline

Redmond L, Oh SR, Hicks C, Weinmaster G, Ghosh A (2000) Nuclear Notch1 signaling and the regulation of dendritic development. Nat Neurosci 3:30-40. CrossRef Medline

Rodriguez GA, Burns MP, Weeber EJ, Rebeck GW (2013) Young APOE4 targeted replacement mice exhibit poor spatial learning and memory, with reduced dendritic spine density in the medial entorhinal cortex. Learn Mem 20:256-266. CrossRef Medline

Sacchetti P, Sousa KM, Hall AC, Liste I, Steffensen KR, Theofilopoulos S, Parish CL, Hazenberg C, Richter LA, Hovatta O, Gustafsson JA, Arenas E (2009) Liver X receptors and oxysterols promote ventral midbrain neurogenesis in vivo and in human embryonic stem cells. Cell Stem Cell 5:409-419. CrossRef Medline

Sahay A, Scobie KN, Hill AS, O'Carroll CM, Kheirbek MA, Burghardt NS, Fenton AA, Dranovsky A, Hen R (2011) Increasing adult hippocampal neurogenesis is sufficient to improve pattern separation. Nature. 472: 466-470. CrossRef Medline

Saunders AM, Strittmatter WJ, Schmechel D, George-Hyslop PH, PericakVance MA, Joo SH, Rosi BL, Gusella JF, Crapper-MacLachlan DR, Alberts MJ (1993) Association of apolipoprotein E allele epsilon 4 with lateonset familial and sporadic Alzheimer's disease. Neurology 43:14671472. CrossRef Medline
Savage JC, Jay T, Goduni E, Quigley C, Mariani MM, Malm T, Ransohoff RM, Lamb BT, Landreth GE (2015) Nuclear receptors license phagocytosis by trem $2+$ myeloid cells in mouse models of Alzheimer's disease. J Neurosci 35:6532-6543. CrossRef Medline

Sestan N, Artavanis-Tsakonas S, Rakic P (1999) Contact-dependent inhibition of cortical neurite growth mediated by notch signaling. Science 286 : 741-746. CrossRef Medline

Shaw T, Martin P (2009) Epigenetic reprogramming during wound healing: loss of polycomb-mediated silencing may enable upregulation of repair genes. EMBO Rep. 10:881-886. CrossRef Medline

Shintani T, Ihara M, Sakuta H, Takahashi H, Watakabe I, Noda M (2006) Eph receptors are negatively controlled by protein tyrosine phosphatase receptor type O. Nat Neurosci 9:761-769. CrossRef Medline

Simon R, Brylka H, Schwegler H, Venkataramanappa S, Andratschke J, Wiegreffe C, Liu P, Fuchs E, Jenkins NA, Copeland NG, Birchmeier C, Britsch S (2012) A dual function of Bcl11b/Ctip2 in hippocampal neurogenesis. EMBO J 31:2922-2936. CrossRef Medline

Sun G, Shi Y (2010) Nuclear receptors in stem cells and their therapeutic potential. Adv Drug Deliv Rev 62:1299-1306. CrossRef Medline

Tang Y, Li T, Li J, Yang J, Liu H, Zhang XJ, Le W (2014) Jmjd3 is essential for the epigenetic modulation of microglia phenotypes in the immune pathogenesis of Parkinson's disease. Cell Death Differ 21:369-380. CrossRef Medline

Tapias V, Greenamyre JT (2014) A rapid and sensitive automated imagebased approach for in vitro and in vivo characterization of cell morphology and quantification of cell number and neurite architecture. Curr Protoc Cytom 68:12.33.1-12.33.22. Medline

Tapias V, Greenamyre JT, Watkins SC (2013) Automated imaging system for fast quantitation of neurons, cell morphology and neurite morphometry in vivo and in vitro. Neurobiol Dis 54:158-168. CrossRef Medline

Tesseur I, Lo AC, Roberfroid A, Dietvorst S, Van Broeck B, Borgers M, Gijsen H, Moechars D, Mercken M, Kemp J, D’Hooge R, De Strooper B (2013) Comment on "ApoE-directed therapeutics rapidly clear beta-amyloid and reverse deficits in AD mouse models." Science 340:924-e. Medline

Veeraraghavalu K, Zhang C, Miller S, Hefendehl JK, Rajapaksha TW, Ulrich J, Jucker M, Holtzman DM, Tanzi RE, Vassar R, Sisodia SS (2013) Comment on "ApoE-directed therapeutics rapidly clear beta-amyloid and reverse deficits in AD mouse models." Science 340:924-f. Medline

Xiao F, Lin LF, Cheng X, Gao Q, Luo HM (2012) Nogo-66 receptor activation inhibits neurite outgrowth and increases beta-amyloid protein secretion of cortical neurons. Mol Med Rep 5:619-624. Medline 